\title{
ORGANIZATIONAL DETERMINANTS OF WAGE MODERATION
}

\author{
By LUCIO BACCARO and MARCO SIMONI*
}

$\mathrm{T}$

HIS article deals with one of the founding themes in the literature on comparative political economy-the impact of industrial relations institutions on cross-country differences in macroeconomic performance- and focuses on the internal governance characteristics of trade union confederations. The literature on the economic effects of industrial relations structures is large and spans several decades. Yet most of it, particularly the newest, ignores internal governance conditions and implicitly assumes that once the structure of collective bargaining is coordinated or centralized, no other organizational factor needs to be in place for wage moderation to materialize. ${ }^{1}$ Recent political economic studies either disregard the internal decision-making process of trade unions ${ }^{2}$ or take at face value the conclusions of neocorporatist studies from the 1980s. ${ }^{3}$

We argue that the internal governance processes within trade union confederations are important for wage moderation but that the relationship is very different from the one hypothesized by classic neocorporatist studies. Controlling for a number of factors, including the degree of collective bargaining coordination, the organizational variable that correlates with moderate wage growth is the degree to which trade union confederations engage in a democratic organizational process that directly involves workers in collective bargaining approval; it is not the leaders' ability to impose their decisions upon lower-level structures and affiliates. Furthermore, the evidence indicates that the coordina-

*The authors wish to thank Joseph Doyle, Thomas Kochan, Peter Hall, Bob Hancké, Rickard Locke, Steve Pischke, Kenneth Scheve, David Soskice, and Peter Swenson for helpful comments on previous versions. Marco Simoni gratefully acknowledges financial support from the British Academy.

${ }^{1}$ Layard, Nickell, and Jackman 2005; Blanchard 2006.

${ }^{2}$ E.g., Mares 2006.

${ }^{3}$ Iversen 1999; Traxler and Kittel 2001.

World Politics 62, no. 4 (October 2010), 594-635

Copyright (C) 2010 Trustees of Princeton University

doi: $10.1017 / \mathrm{S} 0043887110000201$

Downloaded from https:/www.cambridge.org/core. University of Basel Library, on 30 May 2017 at 13:08:00, subject to the Cambridge Core 
tion of collective bargaining and a process of democratic ratification are complements that magnify each other's wage-dampening effect.

We engage in an econometric analysis to document the existence of a relationship of robust dependence between wage moderation and worker involvement in contract approval, and then, through a historical reconstruction of developments in Ireland and Italy, illustrate the causal mechanisms that undergird this statistical association. These are the two countries in our sample in which both the involvement of workers in decision making and the coordination of collective bargaining increased the most, and thus provide an opportunity to investigate in greater detail the uncovered complementarity between wage coordination and rank-and-file involvement and its effect on wage moderation. The case-study analysis suggests that the process of contract approval contributes to wage moderation by strengthening the legitimacy of top union leaders vis-à-vis both individual rank-and-file members and contrarian organized factions. As such, leaders can resolve conflicting claims inside their organizations at lower wage levels than would be achieved (all other things being equal) by a less participatory governance process.

The article is divided into four parts. It begins with an analysis of the theoretical links between the internal organization of collective actors and bargaining outcomes. Next, it moves to an econometric analysis of the determinants of wage growth in sixteen Organization for Economic Cooperation and Development (OECD) countries between 1974 and 2000. Then, through case studies of Ireland and Italy, it illustrates the causal mechanisms by which worker involvement in contract ratification leads to more moderate union demands. Finally, it concludes with remarks on the relationship between wage moderation and employment growth.

\section{Wage Moderation and Organizational Processes within TRADE UNIONS}

A key theme in the comparative political economy literature is the exploration of the institutional conditions that allow wages to grow closely in line with or even below productivity increases. Wage moderation is generally regarded as an important driver of a country's economic performance. Some literature links it to rapid capital accumulation and economic growth in Western Europe after World War II. ${ }^{4}$ More re-

${ }^{4}$ Przeworski and Wallerstein 1982; Eichengreen 1996; Eichengreen and Iversen 1999. 
cent literature argues that the ability of countries such as Ireland or the Netherlands to achieve lower unemployment rates than other European countries in the 1990s and early 2000s is linked to their capacity (associated with effective collective bargaining institutions) to keep wage growth in check. ${ }^{5}$

Political economists seem to have reached a consensus, increasingly shared by macroeconomists, that coordinated or centralized bargaining leads to wage moderation and through that channel to lower unemployment-either directly or by moderating the impact of restrictive monetary policies implemented by independent central banks. ${ }^{6}$ Interestingly, this literature pays little to no attention to the organizational characteristics of the collective actors who participate in bargaining, and therefore implicitly assumes that centralized or coordinated bargaining needs no other condition to deliver wage restraint.

To the extent that organizational factors are taken into account at all, the problem they pose is conceptualized as a horizontal problem of coordination among different unions. For example, where multiple unions try to coordinate on a single wage policy, an individual union is tempted to defect from the agreement especially if it is small enough to reap the benefits of its action (a higher wage) without paying the costs of defection (an increase in consumer prices). ${ }^{7}$ Hence bargaining coordination and the associated wage restraint should be more difficult to achieve where the representational structure is more fragmented and, conversely, easier where it is more concentrated.

In addition to issues of horizontal collaboration or competition among unions, the vertical relationship between peak-level and decentralized structures and between leaders and members also seems relevant to the ability of trade unions to deliver wage moderation. This theme is virtually ignored in the most recent literature but was discussed extensively in the neocorporatist literature of the 1980s. That literature concludes that the most propitious organizational context for wage moderation is one in which trade union confederations are highly centralized, decision-making power is concentrated in the hands of a limited number of peak leaders, and the influence of rank-and-file workers is kept to a minimum. ${ }^{8}$

\footnotetext{
${ }^{5}$ Visser and Hemerijck 1997; Blanchard and Philippon 2004; Baccaro and Simoni 2007.

${ }^{6}$ See, in a very long list, Cameron 1984; Calmfors and Driffill 1988; Soskice 1990; Scharpf 1991; Garrett 1998; Hall and Franzese 1998; Iversen 1999; Soskice and Iversen 2000; Traxler and Kittel 2001; Franzese 2002; Layard, Nickell, and Jackman 2005; Nickell, Nunziata, and Ochel 2005; Mares 2006.

${ }^{7}$ Golden 1993; Iversen 1999; Carlin and Soskice 2006.

${ }^{8}$ Schmitter 1974.
} 
The literature accepts Mancur Olson's argument that more broadly representative (or encompassing) union organizations are more likely to voluntarily agree to wage restraint than small and sectoral ones. However, the literature does not stop there; it also specifies the internal conditions that protect large, encompassing organizations from potentially disruptive centrifugal tendencies. This further specification is necessary because in formally democratic countries trade unions are voluntary associations. Even when wage restraint is in the unions' organizational interests, it is more than likely to conflict with the interests of at least some rank-and-file groups. These groups may conceivably react to this discrepancy either by demanding a shift in union bargaining policy from moderate to more aggressive, or by leaving the more responsible, encompassing organization and joining-or establishing ex novo-other, less encompassing associations better capable of satisfying their specific interests.

Half-descriptively, half-prescriptively, the neocorporatist literature argues that to ensure internal compliance with centralized wage stipulations, decision-making power needs to be concentrated in the hands of a limited number of national leaders (assumed to be more longterm oriented than their rank-and-file counterparts). In addition, these leaders need to be effectively insulated from the disruptive influence of their base. Based on these premises, the neocorporatist literature underscores the importance of monopolistic associations and compulsory or semicompulsory membership. ${ }^{10}$ Readily apparent at least in some portion of the literature is also a less-than-enthusiastic stance in regard to trade union democracy; enabling the rank-and-file to influence union choices through elections and worker referenda threatens to subvert centralized wage restraint. ${ }^{11}$

The literature's widely held view that achieving wage moderation requires union organizations with a capacity to impose leaders' decisions on members ${ }^{12}$ has rarely been submitted to empirical testing. When it has been, results have seemed contradictory. A small number of country studies appear to corroborate it, ${ }^{13}$ but other studies - including large-N ones - find no systematic link between the success of centralized wage regulation and a lack of internal democracy. ${ }^{14}$

\footnotetext{
${ }^{9}$ Olson 1965; 1982.

${ }^{10}$ Schmitter 1974; Panitch 1979; Offe 1981.

${ }^{11}$ Schmitter 1974; Streeck 1988; 1994; Pemberton 1988; Przeworski 1991, 12; Stepan-Norris and Zeitlin 1995

12 This view is found for example in Garrett and Way 1999, 414-15; Golden, Wallerstein, and Lange 1999, 195; Iversen 1999, 48; Traxler and Kittel 2001, 65.

${ }_{13}^{13}$ Streeck 1982; Wolfe 1985; Hardiman 1988.

${ }^{14}$ Regini 1984; Lange 1984; Armingeon 1986; Golden 1993.
} 
We contend that the neocorporatist argument is crucially dependent on two dubious assumptions and a fallacious practical conclusion associated with them. The assumptions are that the rank-and-files' policy preferences are determined outside of the organizational process and are systematically more extreme than the leaders'. The fallacious conclusion is that the only organizational mechanisms available to leaders to ensure worker compliance with centralized agreements are those of hierarchical authority and control, including, for example, the power to sign an agreement independently of workers' consensus, direct appointment of workers' representatives, centralized control over strike funds, and veto power over wage agreements signed by lower-level structures.

Assuming that preferences are exogenous and fixed, it must be noted that if members are systematically more extreme than leaders, then direct rank-and-file control over organizational policy (through procedures like ratification of collective agreements or reelection of union representatives) may indeed lead to militancy and/or unwillingness to compromise. This situation, however, is far from being the norm. For example, in the U.K. in the Thatcher/Major era, union governance reforms that introduced compulsory balloting prior to strikes as a way of limiting union militancy were motivated by exactly the opposite view, namely that leaders have systematically more extreme preferences than members. ${ }^{15}$

In addition, Alessandro Pizzorno's classic account of workers' militancy in Italy ${ }^{16}$ suggests that one should not take for granted that union policy will automatically reflect the preferences of the majority of workers. The unions' power is largely based on their ability to mobilize workers in strikes. Without democratic mechanisms for registering worker preferences, leaders may take their cues from the revealed preferences of a biased subsample - the workers who participate in or promote collective actions. In this way, in the absence of democratic decision-making procedures, extreme preferences may prevail even when the majority is moderate. Within trade unions, this situation would alter the internal balance of power in favor of vocal factions pursuing more militant agendas because workers who identify with these factions are more likely to participate in strikes than workers with less intense preferences. ${ }^{17}$

Furthermore, although it is customary in economic and political economic research to model trade union behavior as if workers' preferences

\footnotetext{
${ }^{15}$ See Undy and Martin 1984, and Undy et al. 1996.

${ }^{16}$ Pizzorno 1978.

${ }^{17}$ Sabel 1981.
} 
were given and fixed and leaders' choices as reflecting the exogenous preferences of the median worker, ${ }^{18}$ these assumptions seem empirically untenable. A paper presented in 2010 based on microdata ${ }^{19}$ shows that even when the issue at stake is highly salient and workers can be expected to have made up their minds about it in advance, more than 30 percent of workers are uncertain about the options being considered before the ratification process is initiated. These workers form their preferences during the ratification process by heeding the advice of union leaders. In particular, they become favorable or unfavorable toward the agreement at stake depending on the way it is presented to them by leaders in assemblies. The resulting aggregate effects are large enough to transform an initially unfavorable majority into a favorable one. In other words, a democratic ratification process does not just register a positive majority but helps to shape it.

The claim about the endogeneity of worker preferences resonates with the growing literature on the preference-shaping effects of democracy. ${ }^{20}$ This literature is no longer just normative or theoretical. There is by now ample empirical evidence that discourse and deliberation have net effects on preference formation and not solely aggregative effects. ${ }^{21}$

In light of the discussion above, neocorporatism's practical conclusion that hierarchical control is the only mechanism available for compliance seems untenable. ${ }^{22}$ We hypothesize that democratic processes, such as assemblies and ratification of agreements, may lead to wage moderation through two mechanisms that are not mutually exclusive. First, if the majority of workers has moderate preferences, union democracy may help this group emerge and prevail against a vocal minority whose mobilization capacities may be greater. Second, to the extent that union leaders manage to persuade their members that their true interests are better served by moderate wage policies, the communicative processes associated with union democracy may contribute to constructing the moderate majority in question. ${ }^{23}$

\footnotetext{
${ }^{18}$ Farber 1978; Kaufman and Martinez-Vazquez 1990; Booth 1995.

${ }^{19}$ Baccaro 2010.

${ }^{20}$ Habermas 1984; Cohen 1989; Habermas 1996; Gutmann and Thompson 1996; Cohen 1996; Bohman 1996.

${ }^{21}$ Luskin, Fishkin, and Jowell 2002; Druckman and Nelson 2003; Barabas 2004; Druckman 2004; Humphreys, Masters, and Sandbu 2006; Luskin, Fishkin, and Hahn 2007; Farrar et al. 2010.

${ }^{22}$ See also Dunleavy 1991.

${ }^{23}$ The relationship between the preferences of leaders and the initial preferences of followers could conceivably take other forms. If leaders and followers are negatively inclined there should not be any union engagement in wage moderation. Alternatively, if they are both favorably inclined, the opposite should happen. In the hypothetical case in which followers are initially favorably inclined, but leaders
} 
We also hypothesize that the importance of internal democratic processes may have increased over time due to the waning of classic political exchange. ${ }^{24}$ In earlier years a democratic process of decision making was probably less important because unions engaging in wage restraint could show their members that they were delivering the goods in other forms (e.g., welfare-state expansion, working-time reductions, or other side payments), and thus had a lesser need to worry about procedural legitimacy. ${ }^{25}$ As time progressed and financial problems limited the further expansion of the welfare state, ${ }^{26}$ it became more difficult for unions to exchange wage moderation with more favorable welfare provisions, or, more generally, increased public spending. ${ }^{27}$ This resonates with the recent literature on new social pacts, i.e., forms of centralized bargaining in which there is no longer a clear quid pro quo. ${ }^{28}$ Reliance on democratic procedures for legitimation may have become more important than in the past. To use Fritz Scharpf's vocabulary, there may have been a transition over time from legitimation through outcomes to legitimation through procedures. ${ }^{29}$

In sum, most of the literature (especially economic) ignores the organizational features of trade unions engaged in centralized or coordinated bargaining and therefore assumes that these features do not matter for wage moderation. Some of the literature argues that only the impact of concentration versus fragmentation of union representation matters. An older neocorporatist literature argues that a union organization in which rank-and-file workers can voice their preferences on wage outcomes is less propitious for wage restraint than a more hierarchical organization. A newer literature however, which we have contributed to, ${ }^{30}$ argues that democratic processes help union leaders mobilize consensus for controversial and potentially unpopular choices. In the next section we test all these hypotheses through multivariate analysis.

\footnotetext{
are against, we would expect that leaders may be able to change the followers' attitudes through deliberative mechanisms. In this paper we focus on the configuration that has most intrigued the literature on wage moderation, namely the one where confederation leaders are favorably inclined towards wage moderation but have to ensure the compliance of an initially reluctant follower base.

${ }^{24}$ Pizzorno 1978b; Mares 2006.

${ }^{25}$ Pizzorno 1978b; Katzenstein 1985.

${ }^{26}$ Pierson 2001.

${ }^{27}$ Mares 2006.

${ }_{28}^{28}$ Regini 1997; Wallerstein, Golden, and Lange 1997; Perez 2000; Compston 2002; Culpepper 2002; Molina and Rhodes 2002; Traxler 2004; Hassel 2006; Hamann and Kelly 2007; Avdagic 2010.

${ }^{29}$ Scharpf 1999.

${ }^{30}$ Baccaro 2003; Baccaro and Simoni 2007.
} 


\section{An Econometric Analysis of the Determinants of Wage Moderation}

\section{Measuring Union Governance Characteristics}

In order to measure the extent of the peak levels' hierarchical control of union confederations over affiliates and members, we followed Lane Kenworthy ${ }^{31}$ and aggregated available information on whether or not the confederation: 1) has the power to appoint affiliates; 2) can veto wage agreements of affiliates; 3) can veto strikes; and 4) has its own strike funds. In this way we obtained a $0-4$ index of confederation hierarchy. ${ }^{32}$

Because no cross-country indicator was available to measure the extent of rank-and-file involvement in collective bargaining by union confederations, we created our own. In doing so, we were faced with two problems. First, we found a dearth of secondary sources detailing the internal procedures of trade unions - a sign that, until recently, the construct was not thought to be particularly relevant for wage behavior. Thus we relied primarily on interviews with trade union leaders. Second, we found union democracy to be a loaded and slippery concept. If one talks with trade unionists about it, one finds that virtually all trade unions may be considered democratic (or non) according to some definition. Those on the left of the union spectrum seem to consider democracy visible in its outcomes. When unions are not vocal and militant it is interpreted as a sign that workers have been hoodwinked by their leaders and that therefore a democratic deficit is present. ${ }^{33} \mathrm{Oth}-$ ers argue that to the extent that the formal procedures and guarantees included in the constitutions of major trade union confederationsnamely the fact that workers are allowed to affiliate freely; have freedom of expression; elect their floor-shop representatives; and elect, either directly or indirectly, the delegates to higher-level structures including the confederation congress - can be likened to those existing in many democratic polities, trade unions are at least as democratic as national governments. ${ }^{34}$

We do not address here the normative issue about what constitutes a genuine union democracy. Our indicator, contract ratification (CR), is

\footnotetext{
${ }^{31}$ Kenworthy 2003.

32 Data from Golden, Lange, and Wallersten 2006 (henceforth referred to as the GLW database). We updated the measure from 1993 to 2000 and coded Ireland based on the same sources used to construct the measure of contract ratification (see below in this article).

${ }_{33}$ See Bertinotti 1991; Minkin 1991, 159-65; Cremaschi 1993.

${ }^{34}$ Willey 1971.
} 
less ambitious and seeks to capture the extent to which rank-and-file workers are involved in the process of approving collective bargaining outcomes at the sectoral and/or national levels. CR varies from 0 to 2 . The score is 2 when national collective agreements, in particular the most politically divisive ones, are adopted through secret ballots among members (or, a fortiori, workers). An intermediate case $(\mathrm{CR}=1)$ is recorded when union leaders only consult workers informally on collective agreements, asking either for a show of hands or for opinions in open assemblies. CR is null when the leadership never consults members over collective agreements or, alternatively, when there are no sectoral or national collective bargaining agreements in the country in question. ${ }^{35}$ The latter rule creates a linkage between contract ratification and bargaining centralization. The correlation between the contract ratification index and a measure of collective bargaining centralization is positive, but far from perfect $(\rho=0.41) .{ }^{36}$ Additionally, it should be emphasized that the measures of confederation hierarchy and contract ratification are orthogonal, not negatively correlated $(\rho=0.07)$. This means that a union confederation could involve the rank-and-file in contract ratification while simultaneously retaining authority to veto contract and strike decisions, make appointments within affiliate organizations, and keep its own strike funds. ${ }^{37}$

All other things being equal, a union that involves the rank-and-file in contract approval should be considered more democratic than one that does not. However, we cannot assess the normative quality of the organizational processes involved and therefore do not mean to imply that a union confederation scoring higher on our index is necessarily more democratic than another scoring lower. Organizational processes within trade union confederations are known to reflect national cultural specificities. ${ }^{38}$ This might contribute to the explanation of why the notion of union democracy is controversial among union practitioners. Like other existing indicators of industrial relations institutions, ${ }^{39}$ the $\mathrm{CR}$ index focuses on objective formal characteristics rather than subjective interpretations of substance.

The CR index was created for sixteen OECD countries between 1974 and 2000. The country scores are based on two waves of interviews

\footnotetext{
${ }^{35}$ This second instance refers to, in our database, Canada and the U.S. The econometric results presented below are robust to alternative or simultaneous dropping of these countries.

${ }^{36}$ This is the variable BARGLEV2 in the GLW database.

${ }^{37}$ An example is the Norwegian LO, which scores 2 out of 2 on contract ratification and 3 out of 4 on confederation hierarchy.

${ }^{38}$ Crouch 1992; Hyman 2001.

${ }^{39}$ Kenworthy 2003.
} 
with trade union leaders participating in the International Labor Organization's (ILO) International Labor Conference (in June 2004 and 2007) and Governing Body (in 2004) in Geneva, Switzerland. ${ }^{40}$ The information was cross-checked with national industrial relations experts as well as with secondary sources, leading to the scores presented in Table $1 .^{41}$

The $0-2$ indicator reveals some interesting differences across countries, including among those that are traditionally considered to have similar trade union structures. Among the Nordic countries, for example, worker ratification is never practiced in Sweden $(\mathrm{CR}=0)$. The constitution of the Swedish trade union confederation (LO) has stated since 1941 that the power to decide over collective agreements and industrial action must be vested in the executive committee of the national union as a condition for membership in the confederation. ${ }^{42}$ The situation is the same in the other two Swedish confederations, the Swedish confederation of professional employees (TCO) and the Swedish confederation of professional associations (SACO). In contrast, the constitution of the Norwegian confederation of trade unions (Norwegian LO) explicitly requires that workers vote on collective agreements through referenda. If less than two-thirds of workers affected by the issue participate in the ballot, the outcome of the referendum is advisory only. If a collective agreement involves more than one union, the confederation may decide to organize a joint ballot with the explicit permission of the unions in question. Similar rules apply to the two other Norwegian confederations, the YS (a confederation of vocational unions) and the AF (a confederation of Norwegian professional associations).

In Denmark, ballots are also regularly organized and workers voting on collective bargaining agreements is tightly linked with the institution of state mediation. When collective bargaining reaches an impasse, the state mediator is entitled by law to propose the terms of a solution that is then voted upon by the unions concerned. Most unions, and particularly the largest ones, organize secret ballots of their membership prior to voting on a proposed solution. Participation rates in these ballots are generally quite low and rejection of the terms is rare though it has happened.

Other interesting differences emerge when comparing Belgium and the Netherlands. In Belgium, the Act of 5 December 1968 presumes

\footnotetext{
${ }^{40}$ See also Simoni 2007.

${ }^{41} \mathrm{~A}$ complete list of interviewees and secondary sources is available from the authors upon request.

${ }^{42}$ Martin 1984.
} 
TABLE 1

Contract Ratification Index

\begin{tabular}{lcc}
\hline \hline Country & Period & Score \\
\hline Australia & $1974-2000$ & 1 \\
Austria & $1974-2000$ & 0 \\
Belgium & $1974-2000$ & 0 \\
Canada & $1974-2000$ & 0 \\
Denmark & $1974-2000$ & 2 \\
Finland & $1974-1984$ & 2 (SAK) \\
& $1985-2000$ & 1 (SAK) \\
& $1974-2000$ & 1 (STTK and \\
France & $1974-2000$ & AKAVA) \\
Germany & $1974-2000$ & 0 \\
Ireland & $1974-1987$ & 1 \\
& $1988-2000$ & 2 \\
Italy & $1974-1992$ & 1 \\
& $1993-2000$ & 2 \\
Netherlands & $1974-2000$ & 1 \\
Norway & $1974-2000$ & 2 \\
Spain & $1974-2000$ & 0 \\
Sweden & $1974-2000$ & 0 \\
U.K. & $1974-2000$ & 1 \\
U.S. & $1974-2000$ & 0 \\
\hline
\end{tabular}

${ }^{\text {a }}$ To obtain a single country score, each score is weighted by confederation membership using the data in Golden, Lange, and Wallerstein (2006). A list of sources is available from the authors upon request.

${ }^{b}$ SAK is the confederation of salaried employees, STTK is the confederation of professional employees, and AKAVA is the confederation of unions for academic professionals.

that the delegates of the organizations involved in collective bargaining have the power to conclude agreements on behalf of those organizations. Therefore decisions concerning collective agreements are left to leaders. For an agreement to be adopted, the leaders need to obtain the approval of their organization's governing body: no rank-and-file vote is required. The largest Belgian union, ACV, justifies its governance system as follows:

"In the heroic times of the trade union movement . . . leaders were nominated directly by the members, who selected . . . those who displayed the greatest dynamism and the liveliest zeal for trade union interests .... But with the further development of membership, the growing complexity of trade unions and the centralization of trade union action caused by changes in industrial life, it 
proved no longer possible for the leaders to be elected directly by the members. ...[O]rdinary members are not always capable of forming a sound judgment of the aptitudes required of possible leaders. Direct election therefore, was replaced by appointment, by delegation and by co-optation." ${ }^{43}$

In the Netherlands, worker participation in collective bargaining negotiation and approval had always been greater than in Belgium. In the period covered by our cross-country indicator, ratification of collective agreements by workers happened in large meetings and not by secret ballot. In November 2003, however, the Dutch trade union federation (FNV, the largest Dutch confederation) ran a ballot of its membership in an effort to ratify a social-pact compromise with an unfriendly government. The referendum was used to outflank radical groups (officials and militants of the main industrial union) and resulted in a narrow victory for the FNV leadership. Balloting has been employed on a number of occasions since then.

In Austria and Germany, union confederations use similar procedures, in both cases allowing for little direct rank-and-file influence. In Austria collective bargaining agreements are generally approved by the leaders of the unions in question without consulting the rank-and-file. Workers are merely informed of the negotiation process and notified of the outcomes of bargaining. If the leaders sense discontent that could undermine their ability to achieve their declared bargaining goals, however, they may consult the members and then make a decision. In Germany collective agreements are approved by the executive bargaining committees and there is no ballot of the members.

The CR measure varies the most across countries and little over time between 1974 and 2000. Indeed, it is time-variant for only three of the sixteen countries, Finland, Italy, and Ireland. It increases in Italy and Ireland and decreases in Finland. Although we cannot exclude measurement error, the near time-invariance of this organizational variable is likely to reflect the reality of the phenomenon we seek to measure. Decision-making procedures within union confederations are likely to change little over time because they are shaped by deeply ingrained organizational practices. Confirming this impression, the measure of confederation hierarchy coded by Miriam Golden, Peter Lange, and Michael Wallerstein ${ }^{44}$ is also predominantly cross-sectional. Indeed, its longitudinal variation is less than that of the contract ratification measure. ${ }^{45}$

${ }^{43}$ Reported in Blanpain 2004, 222.

${ }^{44}$ Golden, Lange, and Wallerstein 2006.

${ }^{45}$ The ratio of within variation to total variation is 26 percent for the contract ratification variable and 9 percent for the confederation hierarchy variable. The indicator of hierarchical power of employer 
However, the near time invariance of the contract ratification variables suggests that the results of any time-series cross-sectional analysis should be interpreted with care.

\section{The Dependent Variable: Wage Growth in Efficiency Units}

To understand whether or not union governance and other institutional features affect economic outcomes, a dependent variable that is likely to be influenced by them must be defined and measured. Different from most previous analyses, which focus on a proxy outcome, e.g., unemployment, we use a direct measure of wage moderation, or, conversely, wage militancy - the measure of wage in efficiency units (WEU) developed by Olivier Blanchard. ${ }^{46}$ In our measure, the real (product) wage is divided by an index of total factor productivity (TFP or Solow residual), which captures technical progress, and then further normalized by the labor share. ${ }^{47}$ The resulting index is a measure of unit labor costs where wages are compared with a steady-state rate of labor productivity that depends solely on technological progress and not also on changes in capital intensity. If the index is greater (smaller) than zero, wages grow faster (slower) than technologically determined productivity increases, and there is wage militancy (moderation).

Different from other possible measures of wage moderation, e.g., unit labor costs, the WEU controls for the endogenous impact that real wage militancy may have on labor productivity. In the short to medium run, firms may react to wage militancy by substituting labor with capital, which is likely to lead to increased labor productivity. Through this channel, then, wage militancy may generate its own compensating productivity increases. ${ }^{48}$ By using Blanchard's measure of WEU we avoid these potential problems of endogeneity. ${ }^{49}$

Tables 2 and 3 begin the analysis with descriptive statistics and simple cross-tabulations. Table 2 displays the average change in the wage in efficiency units (1974-2000) by average level of contract ratification. The country/years with no ratification procedure in place display the highest level of wage militancy ( 0.38 percent). An intermediate level of wage militancy ( 0.14 percent) is associated to intermediate levels of

centralization (see below) also coded by Golden, Lange, and Wallerstein (2006), has no temporal variation at all.

${ }^{46}$ Blanchard 1997; Blanchard 2000, 300-304; Blanchard and Philippon 2004, 3.

${ }^{47}$ Formally, this is weu $=w / \frac{T F P}{\text { wshare }}$.

${ }^{48}$ Hellwig 2004.

${ }^{49}$ A full discussion of the rationale for the choice of the wEU measure and of the assumptions underlying it (within the framework of the Solow-Swan growth model: Harrod-neutral technological progress and economies on the balanced growth path) is beyond the scope of this paper. We refer to Blanchard 2006, ch. 12; and Carlin and Soskice 2006, 470-81, for details. 
TABLE 2

Correlation between Contract Ratification and Wage in EFFICIENCY UNITS

\begin{tabular}{lccc}
\hline \hline & $\begin{array}{c}\text { Contract } \\
\text { Ratification } \\
\text { Average Score } \\
(1974-2000)\end{array}$ & $\begin{array}{c}\text { Wage in } \\
\text { Efficiency Units } \\
\text { Average Year-on-Year } \\
\text { \% Change }\end{array}$ & Frequency \\
\hline $\begin{array}{l}\text { Austria, Belgium, Canada, } \\
\begin{array}{l}\text { France, Germany, Spain, } \\
\text { Sweden, United States }\end{array}\end{array}$ & $\mathrm{CR}=0$ & 0.380 & 216 \\
$\begin{array}{l}\text { Australia, Netherlands, } \\
\text { United Kingdom }\end{array}$ & $\mathrm{CR}=1$ & $(3.441)$ & \\
$\begin{array}{l}\text { Denmark, Finland, Ireland, } \\
\text { Italy, Norway }\end{array}$ & $1<\mathrm{CR}<=2$ & 0.145 & 81 \\
\hline
\end{tabular}

The overall bivariate correlation coefficient between average values of contract ratification and average annual change of wage in efficiency units is $\rho=-0.64$, p-value $=0.008, \mathrm{n}=16$; standard deviation in parenthesis

ratification procedure. Considerable wage moderation (-0.46 percent) is associated to intense ratification procedures. These preliminary results suggest that ratification procedures within trade unions do matter.

Table 3 shows a cross-tabulation of wEU changes by different levels of contract ratification as well as coordination of wage bargaining (wBCOOR). ${ }^{50}$ The cross-tabulation contradicts the hypothesis that a highly coordinated collective bargaining structure is sufficient for wage moderation and that organizational processes have no impact on it. Indeed, at the same levels of highly coordinated collective bargaining (WBCOOR $=2$ ), there is considerable variation in wage militancy/moderation by contract ratification regimes. There is no wage moderation in an institutional configuration characterized by highly coordinated bargaining and no contract ratification, $\Delta \mathrm{WEU}=0.37$ percent (e.g., in Sweden up to the early 1980s and in Belgium in some years of the 1990s), and considerable moderation where bargaining is highly coordinated and contract ratification is at the maximum score, $\Delta \mathrm{WEU}=-1.83$ percent (e.g., in Norway and Denmark and in Ireland in the 1990s).

This cross-tabulation also suggests that contract ratification and wage coordination are complements with respect to the capacity to attain

${ }^{50}$ The latter index, a five-point scale, was created by Lane Kenworthy (2003) and is the combination of four factors: the degree of bargaining centralization, the extent to which governments intervene in wage settlements, informal coordination through powerful associations, and pattern setting. 
TABLE 3

Percentage Change of Wage in Efficiency Units at

Different Combinations of Contract Ratification and

WAGE BARgaining COORDINATION ${ }^{a}$

\begin{tabular}{lccc}
\hline \hline \multirow{2}{*}{$\begin{array}{l}\text { Index of Wage Bargaining } \\
\text { Coordination (WBCOOR) }\end{array}$} & \multicolumn{3}{c}{ Contract Ratification Index (CR) } \\
\cline { 2 - 4 } 0 & 0 & 1 & 2 \\
\hline 0 & 0.200 & 0.129 & 0 \\
0.5 & 51 & 33 & \\
& 0.193 & 0.887 & 0 \\
1 & 42 & 20 & 1.107 \\
& 0.630 & 0.33 & 22 \\
1.5 & 13 & 21 & -0.631 \\
& 0.384 & 0.050 & 23 \\
2 & 49 & 44 & -1.830 \\
& 0.371 & -0.905 & 41 \\
\hline
\end{tabular}

\footnotetext{
${ }^{a}$ Cells report the average percentage change in wage in efficiency units year-on-year and the number of observations.
}

wage moderation. At low levels of wage coordination, which means decentralized bargaining, weak government intervention, no informal coordination, and low pattern-setting (i.e., WBCOOR less than or equal to 1 ), an increase in ratification procedures does not seem to have an impact on wage moderation (rows 1 to 3 ). Rows 2 and 3 suggest that, if anything, more democratic procedures may lead to wage militancy if they are associated with a low level of bargaining coordination. On the contrary, at a higher level of wage coordination (rows 4 and 5), the effects of contract ratification on wage moderation becomes strongerincreasing ratification procedures increases wage moderation. These preliminary findings are further and more systematically explored in the next subsection through multivariate analysis.

\section{A Time-Series Cross-Sectional Analysis}

The theoretical framework underpinning our statistical model is that of a negative relationship between the real wage and unemployment in an imperfectly competitive labor (and product) market. ${ }^{51}$ Wages in efficiency units, i.e., real product wages scaled by a technologically determined measure of labor productivity, are assumed to be set through

\footnotetext{
${ }^{51}$ Carlin and Soskice 1990; Layard, Nickell, and Jackman 2005.
} 
nonmarket mechanisms. Against this backdrop, we estimate a model in which the yearly growth rate of the wage in efficiency units responds to movements in aggregate demand (captured by the lagged unemployment rate) and to structural, supply-side factors, including the institutional and organizational conditions in which collective bargaining takes place.

The estimated equation is

$$
g_{\text {weu }, i t}=\beta_{0}+\sum_{n} \sigma_{n} z_{n, i t}+\sum_{j} \gamma_{j,} x_{j, i t}+\sum_{p} \eta_{p} h_{p, i t}+\alpha_{t}+\varepsilon_{i t}
$$

where $g_{\text {weu }, i t}$ is the yearly growth rate of the wage in efficiency units in country $i$ at time $t$ relative to $\left.t-1\left(g_{\text {weu, it }}=\left(w_{e u}-w_{i t}-u_{i t-1}\right) / w e u_{i t-1}\right)\right)$; the $z$ s are $n$ institutional and organizational variables; the $x$ s are $j$ macroeconomic and policy controls; the $h s$ are $p$ institutional interactions; the $\alpha_{t}$ s are $(\mathrm{t}-1)$ time dummies, capturing time-varying shocks affecting all countries simultaneously; and $\varepsilon_{i, t}$ is the stochastic residual.

The basic vector of institutional and organizational variables is

$$
\sum_{n} \sigma_{n} z_{n, i t}=\sigma_{1} C R_{i t}+\sigma_{2} W C O O R_{i, t}
$$

$\mathrm{CR}$ is the measure of contract ratification discussed above. WBCOOR is the wage bargaining coordination index. Using this index instead of a wage centralization index allows us to control for the additional institutional characteristics of the wage determination system that are incorporated in the coordination construct, i.e., the coordination capacities of employer associations, as underscored by David Soskice. ${ }^{52}$ Bargaining coordination has been shown to lead to wage moderation because it helps collective actors internalize the consequences of their wage policies, ${ }^{53}$ thus a negative sign is expected.

We add to this specification, one by one, additional institutional and organizational variables that have been argued to affect wage pressure. We first add the confederation hierarchy index illustrated above. If the neocorporatist hypothesis were true, the coefficient of this variable would be negative. By including the indicator of contract ratification and the indicator of union hierarchy in the same specification, the two competing hypotheses about the optimal internal structure of union confederations seeking to moderate wage demands are tested simultaneously and their relative weight assessed.

\footnotetext{
52 Soskice 1990.

${ }^{53}$ See Baccaro and Rei 2007, and literature cited therein.
} 
Another model includes the union density rate, which should be positively associated to wage militancy to the extent that it captures the monopoly power of unions. As an alternative measure of union power we use the collective bargaining coverage rate, which can be very high even when the density rate is low (as in the paradigmatic case of France) due to legal provisions for contract extension. This variable, too, should be positively correlated with wage growth.

An organizational feature that may also affect wage behavior is the level of interconfederation concentration. It has been argued that the more concentrated the membership of trade unions (ideally within a single union confederation), the lower the likelihood that the confederations will engage in leapfrogging and cause a wage-wage spiral. ${ }^{54} \mathrm{~A}$ negative sign is therefore expected.

Another model includes a measure of the hierarchical power of employer associations, capturing whether employer associations have the power to impose particular settlements or decisions on their affiliates. The rationale behind including this variable is that wage moderation may not only be a function of the unions' capacity to exercise internal discipline, but is also, if not more, a function of the employers' ability to do likewise within their own ranks. ${ }^{55}$ Still another specification includes a composite index capturing the extent of government intervention in collective bargaining-from noninvolvement, to the setting of minimum wages, all the way to the imposition of wage freezes and prohibition of supplementary local bargaining. The expectation is that higher government involvement in wage determination will slow down wage growth.

The last institutional variable we add is a measure of central bank independence. Various scholars have suggested that a central bank that is not accountable to political authorities can induce trade unions to moderate wages at given levels of unemployment by credibly threatening to deflate the economy. ${ }^{56}$ Based on this argument, we hypothesize a negative sign.

The vector of macroeconomic and policy controls includes

$$
\sum_{j} \gamma_{j} x_{j, i t}=\gamma_{1} U R_{i, t-1}+\gamma_{2} \Delta U R_{i, t-1}+\gamma_{3} U N B E N_{i, t}+\gamma_{4} \Delta T A X_{i, t}+\gamma_{5} \operatorname{TOTS}_{i, t}
$$

where $U R$ is the lagged unemployment rate; $\Delta U R$ is the lagged yearly change in unemployment; $\triangle T A X$ is the change in taxes, including in-

\footnotetext{
${ }^{54}$ Carlin and Soskice 1990, 113; Golden 1993; Iversen 1999.

${ }_{55}$ Martin 1984; Swenson 1991; Swank 2001; Swank and Martin 2001; Thelen 2001; Swenson 2002; Martin and Swank 2004.

${ }_{56}^{56}$ Scharpf 1991; Streeck 1994; Hassel 2003.
} 
come and indirect taxes as well as social security contributions on labor, expressed as percentage of gross domestic product (GDP); UNBEN is a measure of the generosity of unemployment benefits; TOTS captures terms of trade shocks measured as changes in terms of trade (ratio of export prices to import prices) weighted by the openness of the economy (defined as the ratio between imports plus exports to GDP).

We expect both higher levels of unemployment rate as well as change in unemployment to be conducive to wage moderation (negative sign). The inclusion of the latter term captures the possible nonlinearity of the relationship, which implies that the trade-off between unemployment and wage growth should become steeper as unemployment increases. ${ }^{57}$ More generous unemployment benefits (replacement rates) should lead to higher wage outcomes (positive sign) at given levels of unemployment by increasing the reservation wage of workers and thus strengthening their bargaining power. ${ }^{58}$ The effect of changes in taxes is a priori unclear. If there is real wage resistance, i.e., if workers respond to changes in labor taxes that lower the take-home wage by pushing up the pretax wage, then there should be a positive relationship with $g_{\text {wei }}$. If there is no wage resistance, then the pretax product wage should be unaffected. Along similar lines, changes in terms of trade should have a negative sign if there is wage resistance. ${ }^{59}$

We also include two types of interactions. First, we interact contract ratification with wage bargaining coordination ( $\left.\mathrm{CR}^{*} \mathrm{WBCOOR}\right)$. This tests the hypothesis of complementarity that emerged in the previous cross-tabulation of data. We expect a negative sign for the interacted coefficient. The second interaction explores the impact of contract ratification changes over time. As hypothesized above, the need to democratically legitimate the outcomes of peak-level agreements may have increased over time due to the declining availability of side payments that could compensate union members for their short-term losses. ${ }^{60} \mathrm{To}$ test this hypothesis we interact the contract ratification variable with a linear time-trend term (TIME). We expect this interaction to be negative, meaning that the wage-moderating effect of contract ratification should increase over time. ${ }^{61}$

We run various specification and robustness checks in a separate subsection.

\footnotetext{
${ }^{57}$ Layard, Nickell, and Jackman 2005, 365.

${ }^{58}$ Layard, Nickell, and Jackman 2005, 76.

${ }^{59}$ Carlin and Soskice 1990, 294-300; Layard, Nickell, and Jackman 2005, 209-10.

${ }^{60}$ Mares 2006.

${ }^{61}$ A section describing variables and data sources is omitted due to space constraints. It is available from the authors upon request.
} 


\section{ECONOMETRIC RESULTS}

Ordinary least squares (OLS) with panel-corrected standard errors is our estimator of choice. ${ }^{62}$ It allows us to correct for both country-specific heteroskedasticity and spatial correlation of the errors. ${ }^{63}$ Table 4 reports regression results. ${ }^{64}$

The regression results fully corroborate our hypotheses. Across all models, the macroeconomic and policy-related variables perform as expected: high levels of unemployment and of changes in unemployment depress wage growth, while a decline in the price of exports relative to imports, high levels of unemployment benefits, and increases in labor taxes push wages (in efficiency units) up.

Our measure of contract ratification is robustly negatively correlated with the dependent variable (WEU), indicating that the more workers are involved in ratifying collective agreements, the greater the wage moderation. Additionally, and confirming a standard result in the literature, wage bargaining coordination is robustly negatively associated with wage militancy. It seems that the more coordinated the bargaining system, the easier it is, all other things being equal, to ensure wage moderation.

The clear impact of contract ratification is paired with the absence of an impact of union hierarchy (model 2). The coefficient is negative, as corporatist theory would predict, but not significantly different from 0 . Similarly insignificant are the coefficients of other institutional and organizational variables, which might be hypothesized to affect wage pressure: union density (model 3); the degree of collective bargaining coverage (model 4); the concentration of union confederations (model 5 ); the degree of centralization of employer organizations (model 6); the degree of government intervention in wage bargaining (model 7); and the degree of central bank independence (model 8).

${ }^{62}$ The hypothesis of no cross-sectional dependence of the errors is rejected (Breusch-Pagan LM test: $\operatorname{chi} 2(120)=159.392, p=0.0094)$. Similarly rejected is the hypothesis of homoskedasticity (modified Wald test: $\operatorname{chi} 2(16)=231.51, \mathrm{p}=0.000)$. We estimate static models because the null hypothesis of no serial correlation cannot be rejected at standard levels of confidence. Since the result of the Wooldridge test was borderline- $F(1,15)=3.802$, Prob $>F=0.0701$ - as a further check we estimated a dynamic model with the lagged dependent variable among the predictors; the coefficient of this variable was not significantly different from 0 . Results are omitted for reasons of space and are available from the authors upon request.

${ }^{63}$ Beck and Katz 1995.

${ }^{64}$ We did not estimate a two-way fixed-effects model with country dummies as well because an F-test of joint significance could not reject the hypothesis that the country fixed effects were jointly equal to zero: $\mathrm{F}(15,380)=0.80$, Prob $>\mathrm{F}=0.6809$. The time dummies were instead jointly highly significant: $F(27,380)=6.75$, Prob $>F=0.0000$. 
Models 9 and 10 include interaction terms. The complementarity between contract ratification and wage bargaining coordination emerging by the cross-tabulation of data is confirmed in model 9 . The coefficient of the interaction term (CR* $\left.{ }^{*} \mathrm{WBCOOR}\right)$ is negative and significant. At the same time, the marginal effect of each variable is not significantly different from zero when the value of the other is zero. In other words, in a hypothetical country where no ratification procedures are in place and wage bargaining is not coordinated, our estimates suggest that neither a unit increase in wage coordination nor a unit increase in contract ratification would have any significant impact on wages. In this model the sign of the contract ratification coefficient is positivethus providing some support for the corporatist view that worker involvement may lead to greater wage militancy, but only when collective bargaining is uncoordinated.

In model 10, we relax the assumption of a constant contract ratification coefficient and explore how it may vary over time. Interestingly, both the time trend variable and the interaction between time trend and contract ratification (CR*TIME) are negative and significant. The time trend, which proxies for all trended omitted variables, suggests that there is linear decline in wage militancy over time when other determinants are controlled for. The interacted coefficient suggests that the wage-moderating effect of contract ratification becomes stronger over time. ${ }^{65}$

Figure 1 shows in a 95 percent confidence-level band how the effect of contract ratification on wage growth changes over time. This effect is significantly negatively different from zero (at 5 percent) starting from around 1980. We interpret this finding as suggesting that democratically legitimating collective agreements become more important as welfare state expansion and other side payments are no longer much of an option. ${ }^{66}$ Procedural legitimation becomes a substitute for outcome legitimation. ${ }^{67}$

\footnotetext{
${ }^{65}$ We estimated two further models (not reported for reasons of space, but available from the authors): a model including a dummy variable for European Monetary Union (EMU ) countries, and a model with an interaction between wage coordination and central bank independence. The EMU dummy (scoring 1 for EMU members between 1992 and 2000, and 0 otherwise) is not significant. Similarly, and surprisingly given previous results (Hall and Franzese 1998; Iversen 1999), the interaction between wage coordination and central bank independence was not only insignificant but also wrongly (i.e., positively) signed. This finding seems interesting and worthy of further investigation, as it suggests that controlling for the previously overlooked process of contract ratification (which according to our argument helps union confederations moderate their wage demands), the much discussed wagedampening effect of the combination between independent central bank, and coordinated bargaining disappears.

${ }_{66}^{6}$ Pizzorno 1978b; Katzenstein 1985; Pierson 2001; Mares 2006.

${ }^{67}$ Scharpf 1999.
} 


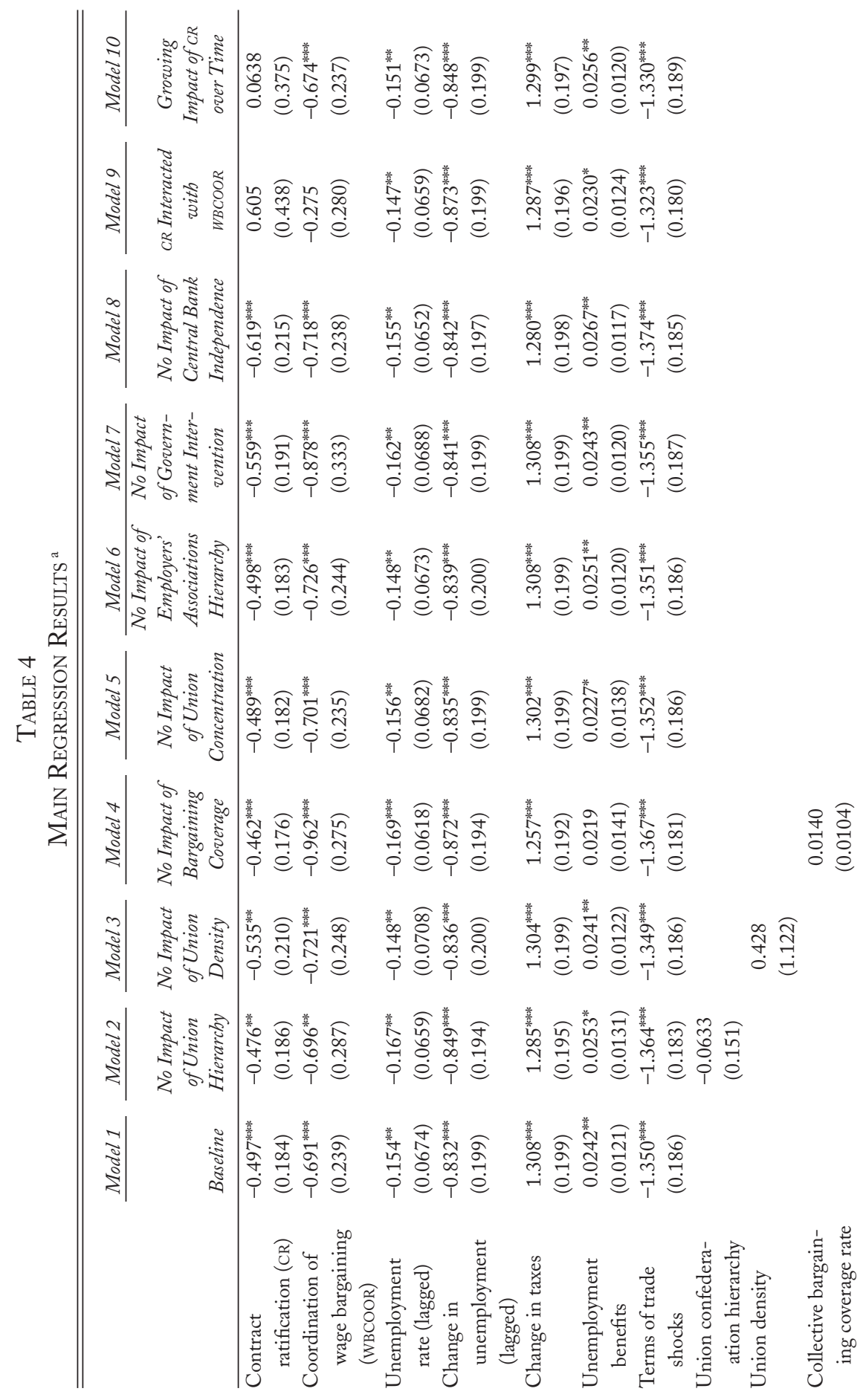




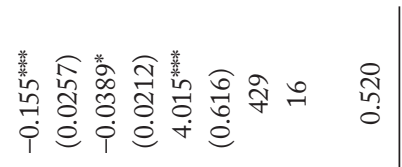

$$
\begin{aligned}
& \text { 善 }
\end{aligned}
$$

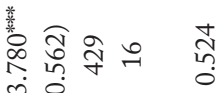

$$
\begin{aligned}
& \text { लं }
\end{aligned}
$$

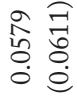

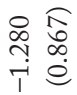

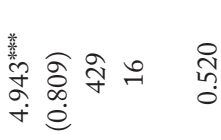

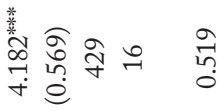

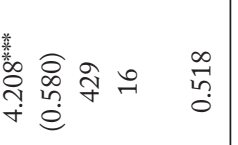

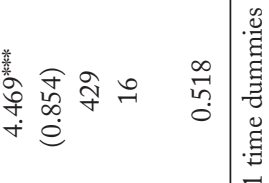

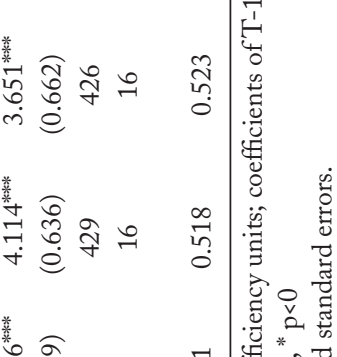

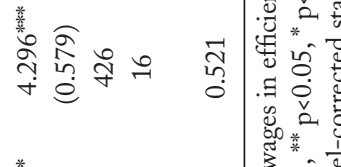

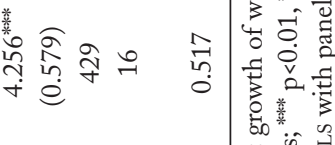
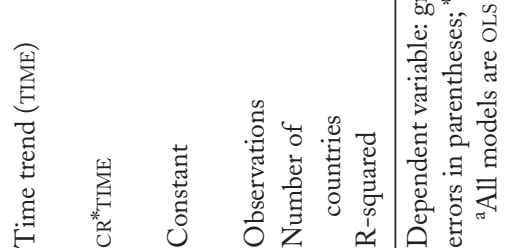$$
\text { 䒿金 }
$$

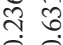

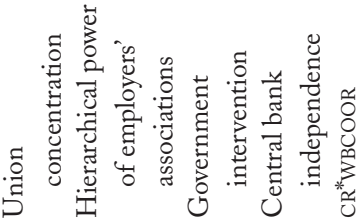




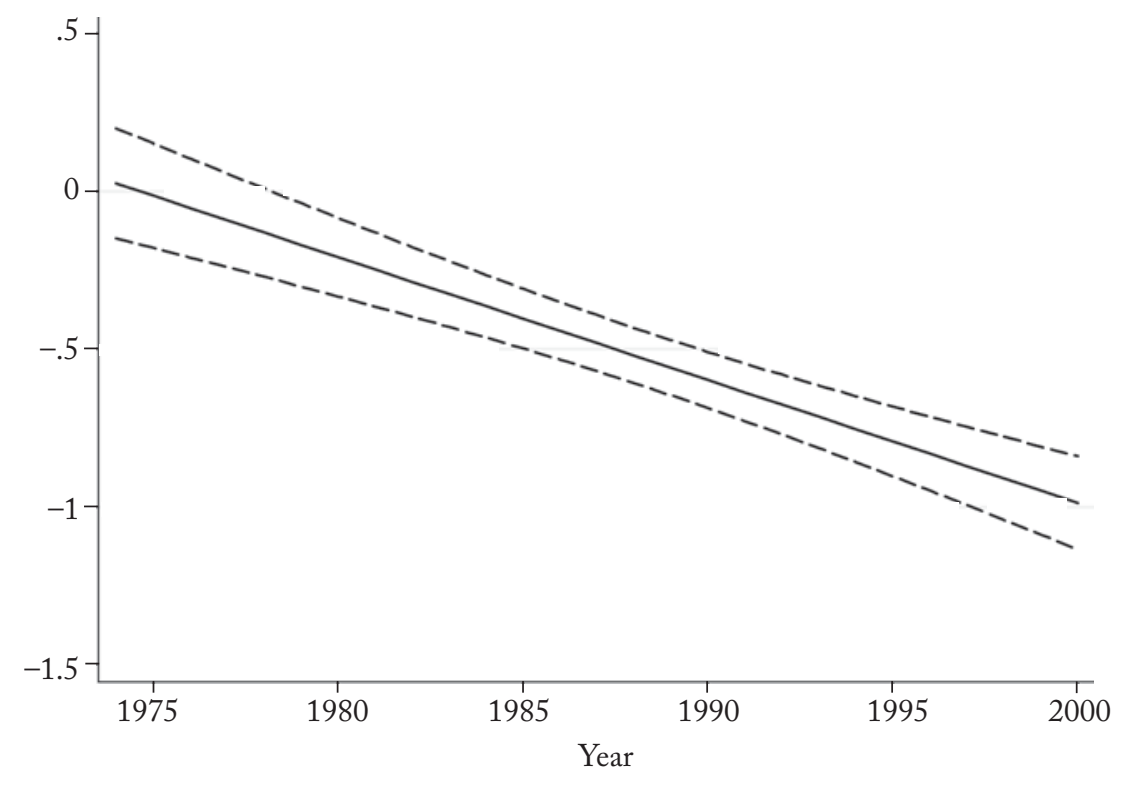

FIGURE 1

Effect of Contract Ratification on Wage Growth in Efficiency Units over Time in a 95 Percent Confidence Interval

\section{Specification and Robustness Checks}

Table 5 reports additional regression results. First, we estimate models that include different operationalizations of our key independent variables, contract ratification and wage bargaining coordination (models 1 and 2). Second, we estimate a reduced-form model by omitting macroeconomic controls that could be endogenously related to the dependent variable (model 3). Third, we estimate the model with averaged data (model 4). Fourth, we estimate two models (5 and 6) in which our key independent variables are lagged. And fifth, we consider models with a different operationalization of the dependent variable: model 7 does not include the interaction between contract ratification and wage coordination; model 8 does.

Our conclusions hold even if we weigh both contract ratification and wage coordination by the degree of collective bargaining coverage (model 1). The reasoning behind this choice is that the impact of particular institutional features is likely to be contingent on the overall importance of collective bargaining in a particular country (captured by the bargaining coverage rate). The impact of the contract ratifica- 
tion and wage bargaining coordination variables on wage growth may be different between countries with high and low coverage. However, the two institutional measures remain significant predictors of wage trends. In model 2 we substitute the measure of wage coordination with a measure of wage centralization. The contract ratification coefficient is still significant but its magnitude is smaller and the standard error larger. While the measures of wage bargaining centralization and wage coordination are highly correlated $(\rho=0.80)$, contract ratification is (by construction) more highly correlated with wage centralization $(\rho=0.41)$ than with wage coordination $(\rho=0.24)$. It is therefore more difficult for OLS to sort out the respective contributions of wage centralization and contract ratification to movements in wages.

We then estimate a reduced-form model, omitting the two controls for the unemployment rate (model 3). This is intended as a further check on possible endogeneity problems (in addition to using one-year lags of the unemployment controls). In other words, it may be suspected that the unemployment rate responds to wage growth in efficiency units. After omitting these terms the two institutional predictors (contract ratification and wage coordination) continue to have negative and significant coefficients. Model 4 runs an estimate using three-year averaged data. ${ }^{68}$ All results are confirmed.

Our results are likewise confirmed if we lag contract ratification and wage coordination by three or four years (model 5 and model 6, respectively). These tests rule out the possibility of reversed causation between wage moderation and the institutional variables, i.e., that the need to reduce wage militancy leads to an increase in bargaining coordination and contract ratification rather than vice versa.

We then estimate the model with macroeconomic controls and institutional predictors using a different operationalization of the dependent variable - the wage share. The reason for this choice is twofold. First, the wage share is essentially a measure of unit labor costs; it is a standard (albeit less refined) proxy for wage militancy. ${ }^{69}$ Second, the measure allows us to estimate a model where both the left-hand side and the right-hand side of the equation are expressed in levels. Unfortunately, data on wages in efficiency units are only available as an index number, thus making it inevitable to express the dependent variable as change. Regression coefficients support our previous conclusions. In

\footnotetext{
${ }^{68}$ Traxler, Blaschke, and Kittel 2001.

${ }^{69}$ Formally, this is wage share $=\frac{w L}{Y}=w / \frac{Y}{L}=$ unit labor costs, where $w$ (wage), $L$ (labor), $Y$ (product).
} 


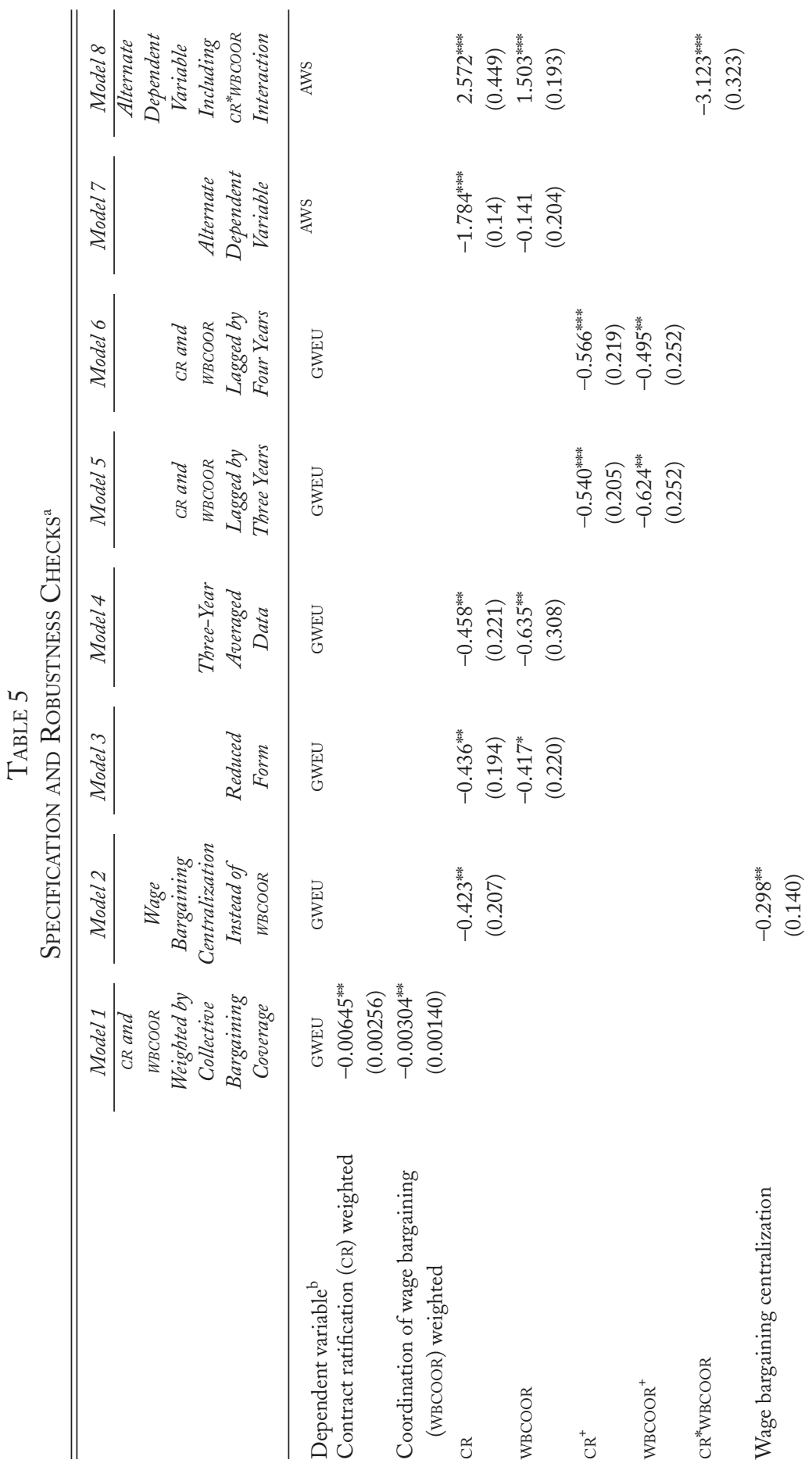




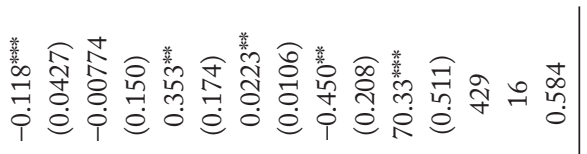

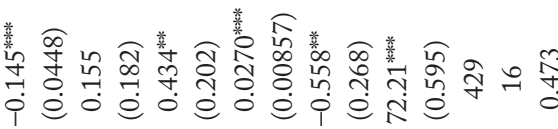

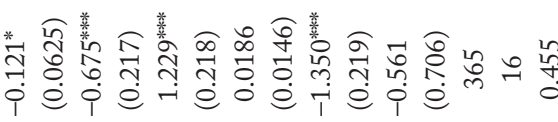

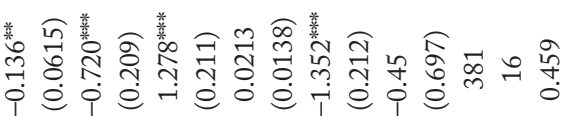

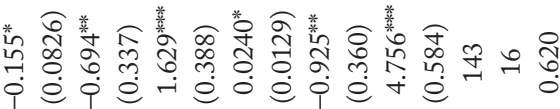

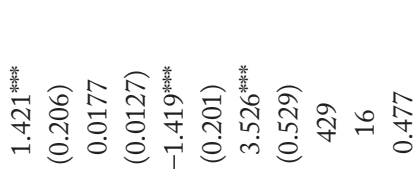

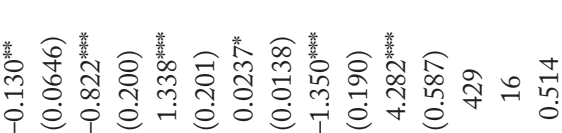

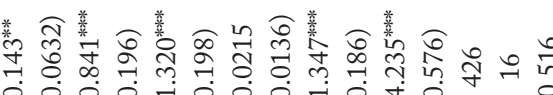

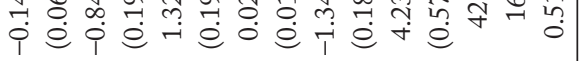

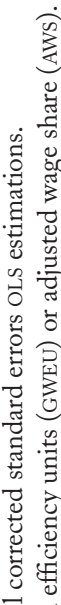

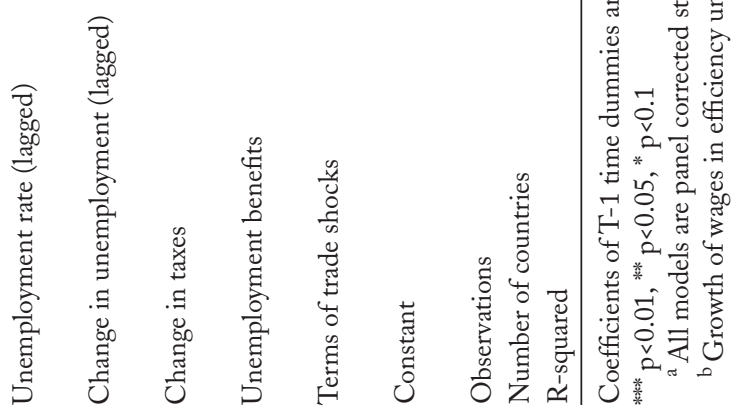


model 7, which examines direct effects, both contract ratification and wage coordination are negatively signed and contract ratification is highly significant. In model 8, with both direct and interactive effects, the interaction term is negative and significant while the direct effects are positive and significant. In other words, when the value of the other variable is zero, neither variable has a negative impact on the wage share, i.e., on unit labor costs. On the contrary, it seems to increase the wage share. It is only the combination of the two variables that matters for labor cost containment. This confirms that wage coordination and contract ratification are complements.

Finally, in Table 6 we estimate a number of purely cross-sectional specifications. ${ }^{70}$ The "between estimator" is in all likelihood not the most appropriate for testing a model in which contract ratification is interacted with wage coordination, which varies more within countries than between. Nevertheless, this extreme test addresses the problem of the nearly time-invariant contract ratification variable. The dependent variable is the average annual change of wage in efficiency units. Our independent variables are also averaged. With only sixteen observations, one per country in the sample, we include only our most important institutional predictors: contract ratification, wage coordination, and their interaction. The macroeconomic controls are not expected to have any impact on the long-run rate of growth of the wage in efficiency units, so they are excluded. We estimate models for the overall period 1974-2000 (models 1 and 2); for 1974-89 (models 3 and 4); and for 1989-2000 (models 5 and 6). In other words, we distinguish between the period of classic political exchange following the two oil crises (1974-89) and the age of new social pacts (1990-2000) in which trade unions were no longer compensated for wage moderation through side payments. ${ }^{71}$

The results of cross-sectional regressions are less straightforward than those of the time-series cross-sectional analysis, but overall are in line with them. Even with only sixteen observations, contract ratification emerges as the most important institutional predictor of wage moderation. Its coefficients for the entire period 1974-2000 are negative and significant (models 1 and 2). Controlling for contract ratification,

\footnotetext{
${ }^{70}$ We also performed (but do not present here) a jackknife analysis (excluding one country at a time) on the model presented in Table 4, column 1. This suggested that the model is robust to presence or absence of particular countries in the sample. In particular, the two institutional variables, wage coordination and contract ratification, do not depend on any particular country for statistical significance.

${ }^{71}$ Regini 1997; Wallerstein, Golden, and Lange 1997; Perez 2000; Compston 2002; Culpepper 2002; Molina and Rhodes 2002; Traxler 2004; Hassel 2006; Hamann and Kelly 2007; Avdagic 2010.
} 
TABLE 6

Cross-Sectional Regressions in Different Periodsa

\begin{tabular}{|c|c|c|c|c|c|c|}
\hline & $\begin{array}{c}\text { Baseline } \\
1974-2000\end{array}$ & $\begin{array}{l}\frac{\text { Model } 2}{1974-2000} \\
\text { with } \\
C R^{*} \text { WBCOOR } \\
\text { Interaction }\end{array}$ & $\begin{array}{c}\text { Baseline } \\
1974-1989\end{array}$ & $\begin{array}{c}\frac{\text { Model } 4}{1974-1989} \\
\text { with } \\
C R^{*} \text { WBCOOR } \\
\text { Interaction }\end{array}$ & $\begin{array}{c}\text { Baseline } \\
\text { 1990-2000 }\end{array}$ & $\begin{array}{l}\frac{\text { Model 6 }}{1990-2000} \\
\text { with } \\
\text { CR*WBCOOR } \\
\text { Interaction }\end{array}$ \\
\hline $\begin{array}{l}\text { Contract } \\
\text { ratification } \\
(\mathrm{CR})\end{array}$ & $\begin{array}{c}-0.430^{* *} \\
(0.171)\end{array}$ & $\begin{array}{c}-0.381^{*} \\
(0.199)\end{array}$ & $\begin{array}{c}0.0638 \\
(0.119)\end{array}$ & $\begin{array}{c}0.0588 \\
(0.149)\end{array}$ & $\begin{array}{l}-1.030^{\text {***** }} \\
(0.288)\end{array}$ & $\begin{array}{c}-0.700^{* *} \\
(0.248)\end{array}$ \\
\hline $\begin{array}{l}\text { Coordination } \\
\text { of wage } \\
\text { bargaining } \\
\text { (wBCOOR) }\end{array}$ & $\begin{array}{c}0.0368 \\
(0.135)\end{array}$ & $\begin{array}{c}-0.0404 \\
(0.175)\end{array}$ & $\begin{array}{c}0.211 \\
(0.149)\end{array}$ & $\begin{array}{c}0.219 \\
(0.196)\end{array}$ & $\begin{array}{c}-0.388 \\
(0.283)\end{array}$ & $\begin{array}{l}-0.675^{* *} \\
(0.250)\end{array}$ \\
\hline $\mathrm{CR}^{*} \mathrm{WBCOOR}$ & & $\begin{array}{c}-0.197 \\
(0.241)\end{array}$ & & $\begin{array}{c}0.0190 \\
(0.250)\end{array}$ & & $\begin{array}{l}-1.011^{\text {**** }} \\
(0.325)\end{array}$ \\
\hline Constant & $\begin{array}{c}0.330^{* *} \\
(0.143)\end{array}$ & $\begin{array}{c}0.405^{*} \\
(0.190)\end{array}$ & $\begin{array}{c}0.140 \\
(0.158)\end{array}$ & $\begin{array}{c}0.133 \\
(0.208)\end{array}$ & $\begin{array}{l}0.727^{* *} \\
(0.325)\end{array}$ & $\begin{array}{l}0.987^{\text {**** }} \\
(0.243)\end{array}$ \\
\hline Observations & 16 & 16 & 16 & 16 & 16 & 16 \\
\hline $\mathrm{R}$-squared & 0.407 & 0.425 & 0.130 & 0.130 & 0.652 & 0.790 \\
\hline
\end{tabular}

Dependent variable: growth of wages in efficiency units yearly average; all models are robust to a jackknife test done by excluding one country at the time; each of the variables interacted is expressed as deviation from the sample mean, i.e., the direct effects of contract ratification and coordination of wage bargaining in the interacted models can be interpreted as referring to the average country; (White-) robust standard errors in parentheses; ${ }^{* * *} \mathrm{p}<0.01,{ }^{* *} \mathrm{p}<0.05,{ }^{*} \mathrm{p}<0.1$

${ }^{\text {a }}$ All models are OLS estimations.

the degree of wage bargaining coordination (i.e., the institution all previous literature has focused on) is not significantly associated with wage moderation in the 1974-2000 regressions. The coefficients of both contract ratification and wage coordination are positive albeit insignificant in the 1974-89 period (models 3 and 4). This is strange but not completely unexpected since the results shown in Figure 1 (which is derived from Table 4, model 10) indicate that the impact of contract ratification becomes significantly different from zero only in the 1980 s. The same coefficients are negative and significant in the period 19902000 (the era of new social pacts). ${ }^{72}$ Additionally, in the $1990-2000$

\footnotetext{
${ }^{72}$ In the interacted models, each of the variables in the interactive term is expressed as deviation from the sample mean. This allows one to interpret the direct effects of contract ratification and coordination of wage bargaining in the interacted models as referring to the average country (for which the interacted term is zero).
} 
period there is a strong complementarity between these institutions (models 5 and 6). ${ }^{73}$

The finding that contract ratification and wage coordination are not associated with wage moderation in the 1974-89 period may be a statistical incident and we do not put much store on it, especially since it contradicts both the theory and the practice of institutionalized wage moderation in this period. Nevertheless, it may indicate that the wage moderating effects of contract ratification, wage coordination, and their interaction apply only to the 1990 s and not to the preceding period. ${ }^{74}$

To summarize, the econometric analysis reveals a new, previously overlooked correlation between wage moderation and the internal governance processes of trade union confederations. It also suggests that worker involvement in contract ratification and collective bargaining coordination are complements: each individually reduces wage militancy (all other things being equal) and together they magnify each other's effect. The effect is particularly robust in the 1990-2000 period-an era in which trade union moderation was no longer compensated by sizeable side-payments.

This article next examines the mechanisms underlying the statistical correlations uncovered through large- $\mathrm{N}$ analysis. We argue that statistical analysis is indispensable to uncovering relationships of covariation among variables, but needs to be complemented by a narrative that illustrates the generative processes by which, through the actions and interactions of human agents, such relationships are produced..$^{75} \mathrm{We}$ focus on developments in Ireland and Italy. These are the only two countries in our sample in which the index of contract ratification increases over time. They are also the two countries in which the index of collective bargaining coordination increases the most between the 1980s and 1990s. In brief, they are the two cases that most clearly exemplify the institutional interaction between bargaining coordination and contract ratification highlighted by the econometric analysis.

\footnotetext{
${ }^{73}$ In another test, we have added one by one to each cross-sectional model all the institutional variables that we have tested in the time-series cross-section analysis (see Table 4). None of the institutional variables reached significance at standard levels in any of the three time periods, barring government intervention, which reached significance at 5 percent in the model for 1974-2000 (although with a sign opposite to expectations), and union density, positive as expected and significant at 1 percent in the model for 1974-89.

${ }^{74}$ We also performed (but do not present here) a jackknife analysis on the model presented in Table 6, column 6. Results held when the model was reestimated excluding one country at a time.

${ }^{75}$ Esser 1996; Goldthorpe 2001, 3; Hedström 2005; Elster 2007.
} 


\section{Wage Bargaining and Union Governance in IRELAnd AND ITALY}

During the 1990s, Ireland and Italy experienced a dramatic transformation of their wage determination systems. Beginning in late 1987, Ireland moved from an essentially decentralized enterprise-based collective bargaining system to a completely centralized and coordinated system, thanks to a succession of seven centralized pacts involving government, employers, and unions, each lasting three years. These pacts regulated wage dynamics in all sectors simultaneously. They also determined exactly what percentage increases, if any at all, could be negotiated at the peripheral levels.

In Italy, too, the 1990s were the decade of centralized bargaining. A centralized agreement abolished wage indexation in 1992 and banned enterprise-level bargaining. In 1993, government, employers, and unions agreed to a new architecture of collective bargaining in which industry-level bargaining (every two years) was tightly linked to government inflation targets and assigned the role of protecting real wages against purchasing-power erosion, while enterprise-level bargaining (every four years) was to redistribute productivity increases. This bargaining system was the object of new negotiations in 1998, which confirmed its dual structure.

The emergence of centralized institutions in Ireland and Italy occurred despite the apparently inhospitable institutional and organizational characteristics of the two countries, at least according to prevailing scholarly views. In 1988, an Irish scholar wrote that "the organizational and political conditions which would tend to be conducive to sustaining neo-corporatist agreements were not well developed in Ireland, therefore concertative wage bargaining could not develop very far. In particular, the trade union movement's authoritative centralization was limited, and it was constrained in its ability to devise a central strategy and secure the compliance of all affiliates." ${ }^{\prime 6}$ Similar judgments were often expressed about Italy. Indeed, Italy was constantly ranked at or near the bottom of the various indexes of corporatism and regarded as a problem case among advanced nations.

In both countries union structure remained relatively fragmented in comparative perspective. ${ }^{77}$ In terms of processes, both union move-

\footnotetext{
${ }^{76}$ Hardiman 1988, 3.

${ }^{77}$ In Ireland (but not in Italy), the ICTU increased its internal concentration through union mergers. There were fifteen such mergers between 1985 and 1989, and seventeen between 1990 and 1994 (Roche and Ashmore 2002, Table 5). With fifty-two unions affiliated to the ICTU in 1995, the Irish labor movement was still more fragmented than most.
} 
ments stepped up their levels of organizational democracy as they arranged extensive consultations of union members (as well as of nonmembers in Italy) combined with binding workers' referendums on key collective agreements. In Ireland, the practice of balloting became more prevalent in the 1990s - it was less widely practiced before then, when consultations were more informal. ${ }^{78}$ To understand how these internal organizational processes helped confederation leaders mobilize internal consensus for policies that were not immediately perceived as beneficial by the union constituency, we focus on the formative moments of wage bargaining coordination in both countries.

\section{The Institutionalization of Coordinated Bargaining}

In Ireland the first centralized pact, the Program for National Recovery (PNR) of 1987, was the most politically contested of the lot. The leaders of the Irish Confederation of Trade Unions (ICTU) were favorably inclined towards it - the country faced a serious macroeconomic crisis, and they were concerned that the government might respond Thatcherstyle with an all-out attack on trade unions. ${ }^{79}$ In particular, public sector unions were afraid they would fare especially poorly in free-for-all bargaining, given the government's emphasis on cutting expenditures. ${ }^{80}$

The various unions affiliated to the ICTU had, however, mixed feelings. In particular, the craft unions (representing skilled workers in the private sector) were against the PNR because they perceived decentralized bargaining as more advantageous for them. Among general unions, the two largest - the Irish Transport and General Workers Union (ITGWU) and the Federated Workers Union of Ireland (FWUI) - supported the deal. The third largest general union, the Amalgamated Transport and General Workers Union (ATGWU), was adamantly opposed to it. As stated above, public sector unions generally favored the agreement.

Aware of the controversial status of the proposed PNR, the ICTU engaged in a highly proceduralized decision-making process that relied on electoral rules similar to those used to elect the American president. If 50 percent plus one voter in a union chose to support the option to

\footnotetext{
${ }^{78}$ Interviews by Baccaro with Esther Lynch, ICTU legislation and social affairs officer, Ireland, June 8, 2007; and with Patricia O'Donovan, former deputy secretary general of the ICTU, Geneva, April 9, 2001; field research.

${ }^{79}$ Interviews by Baccaro with Bill Attley, former general secretary of the FWU and the Services, Industrial, Professional, and Technical Union (sIPTU), Bundoran, Ireland, July 3, 2001; and with David Begg, ICTU general secretary, Bundoran, Ireland, July 4, 2001.

${ }^{80}$ Interview by Baccaro with Peter McLoonne, general secretary of IMPACT, Bundoran, Ireland, July 4, 2001.
} 
endorse (or reject) the PNR agreement, all the delegates of that union voted for (or against) that option in a national convention especially summoned. As with the American process, the rule implied that the ICTU could end up pursuing a policy that was supported by less than a majority of workers if the larger unions approved it by close margins (as they did) while the smaller unions rejected it by larger margins. However, this possibility did not detract from the legitimacy of the collective decision to support the PNR. The unions that lost the vote did not secede or mobilize to pursue their own independent wage policy; they all abided by the will of the majority.

Most of the fifty-six unions attending the special conference on the PNR voted against the agreement, with the largest unions conducting worker ballots to decide how to allocate their votes. The ITGWU, the largest union of all, had forty-eight delegates and its votes were crucial. It ran a ballot of its members and the PNR passed by only 400 votes ${ }^{81}$ The union convention then approved the agreement with 181 votes to 114 .

In Italy, the union decision to engage in centralized bargaining was also highly controversial. The internal process was remarkably similar to the Irish case because in Italy, too, the unions relied on organizational referenda to mobilize consensus among the workers. The 1992 tripartite agreement abolishing wage indexation provoked a major crisis in the unions, especially within the largest confederation, the Italian General Confederation of Labor (CGIL). In the fall of 1992 numerous factory councils mobilized against the abolition of the popular wage indexation mechanism (scala mobile). Interestingly, protesters focused just as much on the content of the agreement (which, of course, they rejected) as on the decision-making process. Because the agreement had not been preceded by a consultation of the workers affected, they claimed it was illegitimate and unrepresentative of the workers' will. ${ }^{82}$

Italian union leaders learned the lesson. The 1993 agreement, unlike its 1992 analogue, was preceded by a binding referendum among the workers - a first in the history of the Italian labor movement. With the grassroots mobilization that had taken place one year earlier fresh in their minds, the confederation leaders asked for and obtained from their bargaining counterparts sufficient time to organize a secret ballot

\footnotetext{
${ }^{81}$ Interview by Baccaro with Bill Attley, former general secretary of the FWUI and SIPTU, Bundoran, Ireland, July 3, 2001.

82 Interviews by Baccaro with Tino Magni, secretary general of the Federazione Impiegati Operai Metalmeccanici (FIOM), Sesto San Giovanni, Italy, June 3, 1997; with Edoardo Bano, head of organization, Labor Chamber of Bergamo, Bergamo, Italy, June 9, 1997; and with Savino Pezzotta, secretary general of the Italian Confederation of Trade Unions, Milan, Italy, June 10, 1997.
} 
among the rank-and-file workers. Although the tentative agreement between the government, employers, and union leaders was reached on July 3, 1993, the actual agreement was not signed until July 23. In the intervening twenty days, the confederation unions set up approximately 30,000 assemblies in the country's major plants and offices to explain the agreement. While 1.5 million workers participated in the vote and 68 percent of them approved the agreement, the consultation identified large pockets of dissent. The employees of some historic automotive plants-Alfa Arese near Milan, Mirafiori in Turin, and oM Iveco in Brescia, for example-voted against the accord (sometimes overwhelmingly). The majority of workers in the cities of Milan and Brescia- two strongholds of the Italian labor movement-also rejected the accord.

The history of the Italian labor movement features several examples of rank-and-file mobilization against union policies that were perceived as too moderate, particularly by industrial workers. In the past, similar mobilization had all but quashed analogous attempts at collective bargaining reform. ${ }^{83}$ This time, however, the dissenting groups did not openly mobilize even though their inaction did not reflect approval of the agreement. For example, the Essere Sindacato faction (the hard liners) within the CGIL declared well before the conclusion of the 1993 negotiation that the forthcoming compromise looked "awful" and that "it would be a mistake to reach an agreement." ${ }^{4}$ Similarly, the Labor Chamber of Brescia promised "a new Hot Autumn." ${ }^{5}$ However, the situation was procedurally different than it had been in 1992. The agreement contained two important responses to the procedural critique previously raised by the dissident factions. First, it institutionalized the regular election of workplace representatives. Second, it was accompanied by a binding consultation among the workers. Although they clearly frowned on the agreement's content, the dissident groups concentrated their energies not on organizing grassroots protest but rather on dissuading workers in the assemblies from approving the agreement.

Some of these groups had something to say about the process. A few, for example, complained that "in the assemblies, only union leaders who were in favor of the agreement [were] allowed to speak." ${ }^{86}$ Yet,

${ }^{83}$ Lange and Vannicelli 1982; Golden 1988.

${ }^{84}$ Il Sole-24 Ore, June 18, 1993.

${ }^{85}$ Il Manifesto, July 10, 1993.

${ }^{86}$ Il Sole-24 Ore, July 23, 1993. 
in the end, none contested the outcome of the consultation, that is, the clear endorsement of the July 1993 agreement by the majority of the Italian workers.

\section{Mechanisms of Consensus Mobilization}

Union leaders have a number of options when faced with the need to push through a bargaining policy that meets with less than enthusiastic approval from their constituencies. They can try to impose it upon those constituencies if institutional and organizational conditions allow them to do so. This is the neocorporatist recipe. Alternatively, they can compensate losers with side payments. This option was increasingly impracticable in the 1990s. Indeed, national bargaining was not made smoother in either Ireland or Italy by an increase in public expenditures. On the contrary, one of the explicit goals of national bargaining was to limit such growth. ${ }^{87}$

Another possibility is for union leaders to assuage internal tensions by scaling up bargaining demands. In this case, internal cohesion would probably be more easily preserved than in the case of hierarchical imposition but (to the extent that unions have market power-the assumption guiding this and other studies) at the cost of greater wage militancy. Still another option is for union leaders to rely on procedural mechanisms to try and persuade dissenting worker groups to go along with a bargaining strategy they do not necessarily like.

This last approach was adopted by union leaders in Ireland and Italy. In both case studies it looks as if a majority of workers favored the moderate bargaining policies proposed by confederation leaders. However, implementing a centralized wage policy implied circumventing a vocal internal faction that claimed to be representative, particularly in the Italian case, of the whole working class. This radical faction had considerable mobilization capacities and, in the Italian case at least, it had previously blocked prior experiments with centralized bargaining.

The adoption of majority rule as a decision-making principle leveled out the different degrees of intensity of the workers' preferences. ${ }^{88}$ The vote of workers who were more likely to engage in collective action counted as much as that of more quiescent workers in determining collective decisions. The fact that the radical factions did not mobilize against the outcome of the vote may reflect a procedural justice effect as described by social psychologists, i.e., an increased willingness to

${ }^{87}$ Baccaro and Simoni 2007; Roche 2007.

${ }^{88}$ Dahl 1956. 
go along with unfavorable outcomes if the process that has generated them can be perceived as procedurally fair. ${ }^{89}$

Although we assume that a favorable majority towards centralized wage regulation was already in re and that the democratic process simply facilitated its emergence, we cannot exclude that the process of debate preceding the vote (in union assemblies) contributed to the creation of such a favorable majority. Indeed, in a companion paper we present microevidence that this may be the case based on a representative random sample of Italian workers covering both those who engaged and those who did not engage in a union referendum..$^{90}$ In other words, leaders may have been able to convince at least some workers that wage moderation was in their best interest by using the force of argument and persuasion. ${ }^{91}$

The evidence suggests that worker ballots augmented the credibility of confederation leaders and weakened the resistance of militant groups by providing clear evidence that the choice of moderate wage demands was not an arbitrary imposition of self-interested union bureaucrats but was supported by the majority of workers. These legitimacy resources substituted for waning material compensation and facilitated internal compliance with peak-level stipulations.

\section{Concluding Remarks}

This article deals with a classic theme in the literature on comparative political economy: understanding what impact particular collective bargaining institutions have on a country's economic performance. We focus on wage moderation (measured as wage growth in efficiency units) as the most direct link between the functioning of a national industrialrelations system and economic outcomes. Econometric analysis shows that worker involvement in the ratification of collective agreements is associated with wage moderation, especially in the 1990s. In addition, it is a complement to coordinated wage bargaining (the institutional characteristic all previous literature has focused upon) - the stronger the involvement of workers in contract ratification, the stronger the effect of coordinated wage bargaining on dampening wage growth.

The case studies of Ireland and Italy highlight, in turn, that wage

\footnotetext{
${ }^{89}$ Lind and Tyler 1988.

${ }^{90}$ Baccaro 2010.

${ }^{91}$ An Italian trade union leader argued that union assemblies have the capacity to change about 20 percent of the workers' preferences (interview with Carlo Spreafico, Milan, Italy, June 16, 1997). See also Habermas 1984.
} 
policies are the result of a heated internal political process within union confederations involving groups with different views about bargaining strategy and feasible wage demands. The case studies also show that unions that go through a process of democratic legitimation are able to reconcile conflicting internal claims at lower levels of wage demands than unions whose leaders make decisions autonomously.

We conclude with a few cautionary notes on the view that wage moderation is unequivocally a good thing for a country's economic performance. It is generally assumed that wage moderation increases employment by pushing the wage-setting curve rightward. However, considering the Irish and Italian cases, the argument for a positive linkage between wage moderation and unemployment reduction is only valid for the former country. Wage militancy and unemployment both declined dramatically in Ireland after the introduction of centralized bargaining in late 1987. A look at the Italian case reveals the relationship is not as clear-cut. Wages slowed down considerably in Italy after the abolition of wage indexation in 1992, but unemployment continued to rise for several years.

This contrast suggests that the impact of wage moderation is possibly contingent on the particular growth path of a country and that lower growth of wages in efficiency units may translate into lower unemployment only in countries such as Ireland, in which foreign demand is by far the most important component of aggregate demand. ${ }^{92}$ In countries with large domestic markets, like Italy, the impact of wage moderation on external competitiveness may be counterbalanced by lower domestic demand and overall lower aggregate demand. This, however, is a topic for another paper.

\section{REFERENCES}

Armingeon, Klaus. 1986. "Formation and Stability of Neo-Corporatist Incomes Policies: A Comparative Analysis." European Sociological Review 2, no. 2:13847.

Avdagic, Sabina. 2010. "When Are Concerted Reforms Feasible? Explaining the Emergence of Social Pacts in Western Europe." Comparative Political Studies 43, no. 5: 628-57.

Baccaro, Lucio. 2003."What is Dead and What is Alive in the Theory of Corporatism." British Journal of Industrial Relations 4, no. 4: 683-706.

- 2010. "Corporatism, Democracy, and the Construction of Interests: Lessons from the Italian Pension Reform." Paper presented at the Council for

\footnotetext{
${ }^{92}$ See Soskice 2007; Carlin and Soskice 2009.
} 
European Studies Seventeenth International Conference, Montreal, Canada, April 15-17.

Baccaro, Lucio, and Diego Rei. 2007. "Institutional Determinants of Unemployment in OECD Countries: Does the Deregulatory View Hold Water?" International Organization 61, no. 3: 527-69.

Baccaro, Lucio, and Marco Simoni. 2007. "Centralized Wage Bargaining and the 'Celtic Tiger' Phenomenon.” Industrial Relations, 46, no. 3: 426-55.

Barabas, Jason. 2004. "How Deliberation Affects Policy Opinions." American Political Science Review 98, no. 4: 687-701.

Beck, Nathaniel, and Jonathan N. Katz. 1995. "What to Do (and Not to Do) with Time-Series Cross-Section Data." American Political Science Review 89, no. 3: 634-47.

Bertinotti, Fausto. 1991. La democrazia autoritaria. Rome: Datanews.

Blanchard, Olivier. 1997. “The Medium Run.” In Olivier J. Blanchard, William D. Nordhaus, and Edmund S. Phelps, eds., Brookings Papers on Economic Activity, vol. 1997, no. 2: 89-158.

. 2000. Comments and Discussion. In Jean-Paul Fitoussi, David Jestaz, Edmund S. Phelps, and Gylfi Zoega, "Roots of the Recent Recoveries: Labor Reforms or Private Sector Forces?" Brookings Papers on Economic Activity 1: 292-304.

. 2006. Macroeconomics. Upper Saddle River, N.J.: Prentice Hall.

Blanchard, Oliver, and Thomas Philippon. 2004. "The Quality of Labor Relations and Unemployment." Working Paper. Cambridge, Mass: National Bureau of Economic Research.

Blanpain, Roger. 2004. "Belgium.” In Roger Blanpain, ed., International Encyclopedia for Labor Law and Industrial Relations, suppl. 282. Boston: Kluwer Law International.

Bohman, James. 1996. Public Deliberation. Cambridge, Mass.: MIT University Press.

Booth, Allison L. 1995. The Economics of the Trade Union. Cambridge: Cambridge University Press.

Calmfors, Lars, and John Driffill. 1988. "Bargaining Structure, Corporatism, and Macroeconomic Performance.” Economic Policy 3, no. 6: 13-61.

Cameron, David. 1984. "Social Democracy, Corporatism, Labour Quiescence, and the Representation of Economic Interest in Advanced Capitalist Society." In John H. Goldthorpe, ed., Order and Conflict in Contemporary Capitalism. Oxford: Clarendon: 143-78.

Carlin, Wendy, and David Soskice. 1990. Macroeconomics and the Wage Bargain: A Modern Approach to Employment, Inflation, and the Exchange Rate. Oxford: Oxford University Press.

- 2006. Macroeconomics: Imperfections, Institutions, and Policies. New York: Oxford University Press.

- 2009. "German Economic Performance: Disentangling the Role of Supply-side Reforms, Macroeconomic Policy and Coordinated Economy Institutions.” Socio-Economic Review 7, no. 1: 67-99.

Cohen, Joshua. 1989. "Deliberation and Democratic Legitimacy." In Alan Hamlin and Philip Pettit, eds., The Good Polity. Oxford: Blackwell: 17-34.

Compston, Hugh. 2002. “The Strange Persistence of Policy Concertation.” In 
Stefan Berger and Hugh Compston, eds., Policy Concertation and Social Partnership in Western Europe: Lessons for the 21st Century. New York: Berghahn Books: 1-16.

Cremaschi, Giorgio. 1993. "La grande burocratizzazione.” Democrazia e Diritto 33, no. 3: 231-47.

Crouch, Colin. 1992. Industrial Relations and European State Traditions. New York: Clarendon Press.

Culpepper, Pepper. 2002. "Powering, Puzzling and 'Pacting': The Informational Logic of Negotiated Reforms.” Journal of European Public Policy 9, no. 5: 774-90.

Dahl, Robert. 1956. A Preface to Democratic Theory. Chicago: University of Chicago Press.

Druckman, James N. 2004. "Political Preference Formation: Competition, Deliberation, and the (Ir)Relevance of Framing Effects." American Political Science Review 98, no. 4: 671-86.

Druckman, James N., and Kjersten R. Nelson. 2003. "Framing and Deliberation: How Citizens' Conversations Limit Elite Influence." American Journal of Political Science 47, no. 4: 729-45.

Dunleavy, Patrick. 1991. Democracy, Bureaucracy and Public Choice. London: Pearson Education.

Eichengreen, Barry. 1996. "Institutions and Economic Growth: Europe since 1945." In Nicholas Crafts and Gianni Toniolo, eds., Economic Growth in Europe since 1945. Cambridge: Cambridge University Press: 38-72.

Eichengreen, Barry, and Torben Iversen. 1999. "Institutions and Economic Performance: Evidence from the Labour Market." Oxford Review of Economic Policy 15, no. 4: 121-38.

Elster, Jon. 2007. Explaining Social Behavior: More Nuts and Bolts for the Social Sciences. New York: Cambridge University Press.

Esser, Hartmut. 1996. "What Is Wrong with 'Variable Sociology'?” European Sociological Review 12, no. 2: 159-66.

Farber, Henry S. 1978. "Individual Preferences and Union Wage Determination: The Case of the United Mine Workers." Journal of Political Economy 86, no. 5: 932-42.

Farrar, Cynthia, James S. Fishkin, Donald P. Green, Christian List, Robert C. Luskin, and Elyzabeth L. Paluck. 2010. "Disaggregating Deliberation's Effects: An Experiment within a Deliberative Poll." British Journal of Political Science 40, no. 2: 333-47.

Franzese, Robert J. 2002. Macroeconomic Policies of Developed Democracies. New York: Cambridge University Press.

Garrett, Geoffrey. 1998. Partisan Politics in the Global Economy. Cambridge: Cambridge University Press.

Garrett, Geoffrey, and Christopher Way. 1999. "Public Sector Unions, Corporatism, and Macroeconomic Performance." Comparative Political Studies 32, no. 4: 411-34.

Golden, Miriam. 1988. Labor Divided: Austerity and Working-Class Politics in Contemporary Italy. Ithaca, N.Y.: Cornell University Press.

. 1993. "The Dynamics of Trade Unionism and National Economic Performance." American Political Science Review 87, no. 2: 439-54.

Golden, Miriam A., Peter Lange, and Michael Wallerstein. 2006. Union Central- 
ization among Advanced Industrial Societies: An Empirical Study, at http://www .shelley.polisci.ucla.edu/. Version dated June 16, 2006.

Golden, Miriam A., Michael Wallerstein, and Peter Lange. 1999. "Postwar Trade-Union Organization and Industrial Relations in Twelve Countries." In Herbert Kitschelt, Peter Lange, Gary Marks, and John D. Stephens, eds., Continuity and Change in Contemporary Capitalism. New York: Cambridge University Press.

Goldthorpe, John H. 2001. "Causation, Statistics, and Sociology." European Sociological Review 17, no. 1: 1-20.

Gutmann, Amy, and Dennis F. Thompson. 1996. Democracy and Disagreement. Cambridge, Mass.: Harvard University Press.

Habermas, Jürgen. 1984. The Theory of Communicative Action. Boston: Beacon Press.

-1996. Between Facts and Norms. Cambridge, Mass.: MIT University Press.

Hall, Peter A., and Robert J. Franzese. 1998. "Mixed Signals: Central Bank Independence, Coordinate Wage-Bargaining, and European Monetary Union.” International Organization 52, no. 3: 505-35.

Hamann, Kirsten, and John Kelly. 2007. "Party Politics and the Reemergence of Social Pacts in Western Europe." Comparative Political Studies 40, no. 8: 971-94.

Hardiman, Niamh. 1988. Pay, Politics, and Economic Performance in Ireland 19701987. Oxford: Clarendon Press.

Hassel, Anke. 2003. "The Politics of Social Pacts." British Journal of Industrial Relations 41, no. 4: 707-26.

- 2006. Wage Setting, Social Pacts and the Euro: A New Role for the State. Amsterdam: Amsterdam University Press.

Hedström, Peter. 2005. Dissecting the Social: On the Principles of Analytical Sociology. New York: Cambridge University Press.

Hellwig, Martin. 2004. "The Relation between Real Wage Rates and Employment: An Intertemporal General-Equilibrium Analysis." German Economic Review 5, no. 3: 263-95.

Humphreys, Macartan, William A. Masters, and Martin E. Sandbu. 2006. "The Role of Leaders in Democratic Deliberations: Results from a Field Experiment in São Tomé and Príncipe." World Politics, 58, no. 4: 583-622.

Hyman, Richard. 2001. Understanding European Trade Unionism: Between Market, Class and Society. London: Sage.

Iversen, Torben. 1999. Contested Economic Institutions: The Politics of Macroeconomics and Wage Bargaining in Advanced Democracies. Cambridge: Cambridge University Press.

Katzenstein, Peter. 1985. Small States in World Markets: Industrial Policy in Europe. Ithaca, N.Y.: Cornell Univeristy Press.

Kaufman, Bruce E., and Jorge Martinez-Vazquez. 1990. "Monopoly, Efficient Contract, and Median Voter Models of Union Wage Determination: A Critical Comparison.” Journal of Labor Research 11, no. 4: 401-23.

Kenworthy, Lane. 2003. "Quantitative Indicators of Corporatism.” International Journal of Sociology 33, no. 3: 10-44.

Lange, Peter. 1984. Union Democracy and Liberal Corporatism: Exit Voice and Wage Regulation in Postwar Europe. Cornell Studies in International Affairs Occasional Paper. Ithaca, N.Y.: Cornell University Press. 
Lange, Peter, and Maurizio Vannicelli. 1982. "Strategy under Stress: The Italian Union Movement and the Italian Crisis in Developmental Perspective." In Peter Lange, George Ross, and Maurizio Vannicelli, eds., Unions, Change, and Crisis. Boston: George Allen and Unwin: 95-206.

Layard, Richard, Stephen Nickell, and Richard Jackman. 2005. Unemployment: Macroeconomic Performance and the Labour Market. New York: Oxford University Press.

Lind, E. Allan, and Tom R. Tyler. 1988. The Social Psychology of Procedural Justice. New York: Plenum.

Luskin, Robert C., James S. Fishkin, and Kyu S. Hahn. 2007. "Deliberation and Net Attitude Change." Paper presented at the European Consortium for Political Research general conference, Pisa, Italy, September 6-8.

Luskin, Robert C., James S. Fishkin, and Roger Jowell. 2002. "Considered Opinions: Deliberative Polling in Britain.” British Journal of Political Science 32, no. 3: 455-87.

Mares, Isabela. 2006. Taxation, Wage Bargaining, and Unemployment. Cambridge: Cambridge University Press.

Martin, Andrew. 1984. “Trade Unions in Sweden.” In Peter Gourevitch, Andrew Martin, and George Ross, eds., Unions and Economic Crisis: Britain, West Germany and Sweden. London: Allen and Unwin: 189-359.

Martin, Cathie J., and Duane Swank. 2004. "Does the Organization of Capital Matter? Employers and Active Labor Market Policies at the National and Firm Levels." American Political Science Review 98, no. 4: 593-611.

Minkin, Lewis. 1991. The Contentious Alliance. Edinburgh: Edinburgh University Press.

Molina, Oscar, and Martin Rhodes. 2002. "Corporatism: The Past, Present and Future of a Concept." Annual Review of Political Science 5: 305-31.

Nickell, Stephen, Luca Nunziata, and Wolfgang Ochel. 2005. "Unemployment in the OECD since the 1960s. What Do We Know?” The Economic Journal 115, no. 500: 1-27.

Notermans, Ton. 2000. Money, Markets, and the State: Social Democratic Economic Policies since 1918. Cambridge: Cambridge University Press.

Offe, Claus. 1981. "The Attribution of Public Status to Interest Groups: Observations on the West German Case." In Suzanne D. Berger, ed., Organizing Interest in Western Europe. New York: Cambridge University Press: 123-58.

Olson, Mancur. 1965. The Logic of Collective Action: Public Goods and the Theory of Groups. Cambridge, Mass.: Harvard University Press.

- 1982. The Rise and Decline of Nations: Economic Growth, Stagfation, and Social Rigidities. New Haven: Yale University Press.

Panitch, Leo. 1979. “The Development of Corporatism in Liberal Democracies.” In Philippe Schmitter and Gerhard Lehmbruch, eds., Trends Toward Corporatist Intermediation. London, Sage: 119-48.

Pemberton, James. 1988. "A 'Managerial' Model of the Trade Unions." The Economic Journal 98, no. 392: 755-71.

Perez, Sofia. 2000. "From Decentralization to Reorganization: Explaining the Return to National Bargaining in Italy and Spain." Comparative Politics 32, no. 4: 437-58.

Pierson, Paul, ed. 2001. The New Politics of the Welfare State. Oxford: Oxford University Press. 
Pizzorno, Alessandro. 1978a. "Le Due Logiche Dell'azione Di Classe.” In Alessandro Pizzorno, ed., Lotte Operaie E Sindacato: Il Ciclo 1968-72 in Italia. Bologna: Il Mulino: 7-45.

. 1978b. "Political Exchange and Collective Identity in Industrial Conflict." In Colin Crouch and Alessandro Pizzorno, eds., The Resurgence of Class Conflict in Western Europe since 1968. London: Macmillan.

Przeworski, Adam. 1991. Democracy and the Market: Political and Economic Reforms in Eastern Europe and Latin America. New York: Cambridge University Press.

Przeworski, Adam, and Michael Wallerstein. 1982. "The Structure of Class Conflict in Democratic Societies." American Political Science Review 76, no. 2: 215-38.

Regini, Marino. 1984. "The Conditions for Political Exchange: How Concertation Emerged and Collapsed in Italy and Great Britain.” In John H. Goldthorpe, ed., Order and Conflict in Contemporary Capitalism. Oxford: Clarendon: 124-42.

- 1997. "Still Engaging in Corporatism? Recent Italian Experience in Comparative Perspective." European Journal of Industrial Relations 3, no. 3: 259-78.

Roche, William K. 2007. "Social Partnership in Ireland and New Social Pacts." Industrial Relations 46, no. 3: 395-425.

Roche, William K., and Jacqueline Ashmore. 2002. "Irish Unions: Testing the Limits of Social Partnership.” In Peter Fairbrother and Gerard Griffin, eds., Changing Prospects for Trade Unionism. New York: Routledge: 137-76.

Sabel, Charles F. 1981. "The Internal Politics of Trade Unions.” In Suzanne Berger, ed., Organizing Interests in Western Europe. New York: Cambridge University Press: 209-44.

Scharpf, Fritz W. 1991. Crisis and Choice in European Social Democracy. Ithaca, N.Y.: Cornell University Press.

- 1999. Governing in Europe: Effective and Democratic? Oxford: Oxford University Press.

Schmitter, Philippe. 1974. "Still the Century of Corporatism?" Review of Politics 36, no. 1: 85-131.

Simoni, Marco. 2007. "The Renegotiated Alliance between the Left and Organised Labour in Western Europe.” Ph.D. diss., London School of Economics and Political Science.

Soskice, David. 1990. "Wage Determination: The Changing Role of Institutions in Advanced Industrialised Countries." Oxford Review of Economic Policy 6, no. 4: 36-61.

- 2007. "Macroeconomics and Varieties of Capitalism." In Bob Hancké, Martin Rhodes, and Mark Thatcher, eds., Beyond Varieties of Capitalism. Confict, Contradictions, and Complementarities in the European Economy. Oxford: Oxford University Press.

Soskice, David, and Torben Iversen. 2000. "The Nonneutrality of Monetary Policy with Large Price or Wage Setters." Quarterly Journal of Economics 115, no. 1: 265-84.

Stepan-Norris, Judith, and Maurice Zeitlin. 1995. "Union Democracy, Radical Leadership, and the Hegemony of Capital." American Sociological Review 60, no. 5: 829-50. 
Streeck, Wolfgang. 1982. "Organizational Consequences of Corporatist Cooperation in West German Labor Unions." In Gerhard Lehmbruch and Philippe C. Schmitter, eds., Patterns of Corporatist Policy-Making. Beverly Hills: Sage. 1988. "Editorial Introduction to Special Issue on Organizational Democracy in Trade Unions.” Economic and Industrial Democracy 9, no. 3: 307-18.

_ 1994. "Staat und Verbände: Neue Fragen. Neue Antworten?" Politische Vierteljahresschrift. Sonderheft 25: 7-34.

Swank, Duane. 2001. "Political Institutions and Welfare State Restructuring: The Impact of Institutions on Social Policy Change in Developed Democracies. In Paul Pierson, ed., The New Politics of the Welfare State. Oxford: Oxford University Press.

Swank, Duane, and Cathie J. Martin. 2001. "Employers and the Welfare State: The Political Economic Organization of Firms and Social Policy in Contemporary Capitalist Democracies." Comparative Political Studies 34, no. 8: 889923.

Swenson, Peter. 1991. "Bringing Capital Back In, or Social Democracy Reconsidered: Employer Power, Cross-Class Alliances, and Centralization of Industrial Relations in Denmark and Sweden." World Politics 43, no. 4: 513-44.

- 2002. Capitalists Against Markets: The Making of Labor Markets and Welfare States in the United States and Sweden. Oxford: Oxford University Press.

Thelen, Katheleen A. 2001. "Varieties of Labor Politics in the Developed Democracies." In Peter A. Hall and David Soskice, eds., Varieties of Capitalism: The Institutional Foundations of Comparative Advantage. New York: Oxford University Press.

Traxler, Franz. 2004. "The Metamorphoses of Corporatism: From Classical to Lean Patterns.” European Journal of Political Research 43, no. 4: 571-98.

Traxler, Franz, Sabine Blaschke, and Bernhard Kittel. 2001. National Labour Relations in Internationalized Markets. Oxford: Oxford University Press.

Undy, Roger, Patricia Fosh, Huw Morris, Paul Smith, and Roderick Martin. 1996. Managing the Unions: The Impact of Legislation on Trade Unions' Behaviour. Oxford: Clarendon Press.

Undy, Roger, and Roderik Martin. 1984. Ballots and Trade Union Democracy. Oxford: Blackwell.

Visser, Jelle, and Anton Hemerijck. 1997. A Dutch Miracle: Job Growth, Welfare Reform and Corporatism in the Netherlands. Amsterdam: Amsterdam University Press.

Wallerstein, Michael, Miriam Golden, and Peter Lange. 1997. "Unions, Employers' Associations, and Wage-Setting Institutions in Northern and Central Europe, 1950-1992." Industrial and Labor Relations Review 50, no. 3: 379-401.

Willey, Richard J. 1971. "Democracy in the West German Trade Union: A Reappraisal of the 'Iron Law." Sage Professional Papers in Comparative Politics, 01-023, no. 2. Beverly Hills: Sage Publications.

Wolfe, Joel D. 1985. "Corporatism and Union Democracy: The British Miners and Incomes Policies, 1973-74.” Comparative Politics 17, no. 4: 421-36. 